\title{
On the Growth of some Lamellibranchs in Relation to the Food-supply of Fishes.
}

\author{
By
}

\author{
E. Ford, A.R.C.Sc.,
}

Naturalist at the Plymouth Laboratory.

With an Appendix and Plates I to III and 5 Figures in the Text.

\section{CONTENTS.}

Introduction

Young stages of various species

Spisula elliptica from Queen's Ground

Syndosmya alba from Bigbury Bay .

Cardium echinatum from Bigbury Bay

Spisula solida from Start Bay

Mactra stultorum

Lutraria elliptica

Lutraria oblonga

Nucula nitida

Cultellus pellucidus

DURING a study of the fauna of the level sea-bottom off Plymouth on which a report has already appeared in this Journal (Ford, 1923), the samples taken in the Petersen bottom-sampler and in the conical dredge were preserved in alcohol and retained. A subsequent re-examination of the accumulated material has provided information on the growth of a number of lamellibranchs, which forms the subject matter of the present paper. As the samples were collected according to a programme arranged expressly to determine the animal communities represented, it was not to 
be expected that they would yield complete data on the growth of a particular species, but the results are interesting and useful when considered in their relation to the food supply of our food-fishes. I must again acknowledge my indebtedness to Mr. R. Winckworth of Brighton for his continued assistance in identification and measurement of specimens. Such expert confirmation of identification was naturally desirable in dealing with the growth of species from the earliest stages. Throughout the paper the term "length" is adopted, meaning the greatest anteroposterior dimension of the shell. This term was used by Weymouth (1923) who gave a figure on page 20 which shows clearly the measurement to which the term is applied. I have also used "length" as a measure of growth-rings on the surface of shells. In Fig. 7 on Plate III, $\mathrm{l}_{2}$ is the length of the second ring on a shell of Spisula solida. Thirty-three genera of lamellibranchs are represented in the material of which all but nine appear among the records compiled by Todd (1907) and Blegvad (1917) of the contents of the stomachs of fishes which include dab, flounder, long-rough dab, plaice, sole, cod, haddock, whiting, cat-fish, viviparous blenny, fresh-water eel, herring and mackerel.

Before the potential value of a bed of lamellibranchs as food for fishes can become known, the precise food-value of the successive stages in the life-history of each lamellibranch must be determined. One species, such as Syndosmya alba, may never grow beyond a size which a medium. dab could easily swallow whole, whereas another, such as Cyprina islandica, although it may be easily devoured in its early life, will soon grow to a size quite beyond the largest of shell-eating fish, and thus be relatively useless to fishes except for such soft parts as may be exposed. In quantitative estimations of fish-food similar to those made by the Danish investigators, this fact needs careful consideration, and the case of a bed of Spisula solida in Start Bay may serve as an illustration. Following the shore-line in quite shallow water for several miles in Start Bay, a rich bed of this species has been located where the observed density in November, 1923, reached 2000 large individuals per square metre in several places. What was the potential value of that bed as food, say, for plaice? From the results of the measurement of the shells taken, I imagine that they would all be too big at that time for small plaice, and many beyond the capacity of large plaice. A reasonable approximation could thus only be made by one having knowledge of the limits of size of Spisula solida eatable by varying sizes of plaice. The location of these large uneatable individuals is, of course, most valuable, for if and when they give rise to a successful fall of spat, the whole area may become a rich source of food for even small plaice. Reference was made above to the case of species which when fully grown may be too big to be swallowed whole, but may yet fall victims to fishes who are 
able to bite off exposed soft parts sueh as the foot and syphons. Todd (1907) has shown that in the North Sea plaice may feed extensively on the feet of razor shells (Ensis sp.), while Blegvad (1917, p. 43) refers to the biting off of the syphons of large Mya arenaria by fresh-water eels in Danish waters. An interesting parallel to these two instances is provided in the action of the bottom-sampler on one occasion in Torbay, where twenty-five syphons of Lutraria elliptica, with but four whole individuals, came up in a haul, showing that the sampler had been able to nip off the syphons, but had left the bodies in the ground soil. There are cases on record of the stomachs of fishes being found to contain recognisable soft parts of large lamellibranchs, but with no trace of shell whatever, and it is of interest to discover how the fishes have managed to extract the flesh. Blegvad (1917, pp. 43-45) tells of fresh-water eels in Bramsnaesvig managing to extract the soft parts of large mussels (Mytilus edulis), great quantities of which, neatly picked out from the shells, may be found in stomachs. In the same locality, eels also contrive to extract the soft parts of Scrobicularia plana, and the siphon, mantle and gills may be sufficiently well preserved in the stomach contents to permit of the determination of species. Blegvad advances as a possible explanation of this unusual method of feeding the suggestion that eels devour the soft parts from shells recently opened by crabs and the starfish Asterias, after driving off the latter. Early in June, 1924, I was informed that several Plymouth fishermen had noted and remarked that the stomachs of their trawled fish from waters outside the Eddystone lighthouse contained the soft parts of "Queens" (Pecten opercularis), with no shell at all. Unfortunately I could obtain no practical confirmation of this, but in view of Blegvad's experience, there seems no reason to question its possibility, although it is difficult to offer an explanation of the means by which the fish had extracted the flesh from the shells, if the lamellibranchs were healthy.

The free-swimming larval stages of lamellibranchs may not enter largely into the diet of fishes, although Lebour (1920, p. 278) records them from larval and postlarval herring, and Blegvad (1917, p. 69) from adult herring and mackerel, but from the time of settlement of the spat and life on the sea-bottom is commenced, their importance is asserted. If size is an important factor, then the greatest number of species of lamellibranchs will be available to fishes during the early bottom stages, so that any evidence on the times of occurrence of spatting of any species will be of value. For instance, knowledge of the spatting time or times of Spisula solida would enable a prediction to be made of an increased richness of the Start Bay bed. In Table I (p. 534), details of the capture of small individuals of a number of species are given, although it is realised that the mere presence of small individuals does not necessarily indicate 
recent settlement of spat. At a later stage in this paper several species will be considered in which there is a big fall of spat during late spring and early summer followed by a period of growth during summer and early autumn, and then by an almost complete cessation of growth from late autumn until the following spring. Quite small individuals, however, may be taken at almost any time, but it will be seen that an individual spatted towards the end of the growth period will remain small throughout the winter until the new spring growth commences. If, on a given

TABLE I.

\begin{tabular}{|c|c|c|c|c|c|}
\hline $\begin{array}{l}\text { Species. } \\
\text { Mytilus edulis }\end{array}$ & $\begin{array}{l}\text { Date. } \\
\text { July, } 1922\end{array}$ & $\begin{array}{c}\text { Locality. } \\
\text { Queen's Ground }\end{array}$ & $\begin{array}{c}\text { individual } \\
\text { measured } \\
-\end{array}$ & $\begin{array}{l}\text { ls length. l} \\
\text { d. mm. } \\
\text { (Many small } \\
\text { specimens) }\end{array}$ & $\begin{array}{l}\text { length. } \\
\text { mm. }\end{array}$ \\
\hline Syndosmya alba & June 9th, 1922 & Bigbury Bay & 813 & $2-11$ & $5 \cdot 5$ \\
\hline , & May 30th, 1923 & , & 115 & $2-6$ & $2 \cdot 5$ \\
\hline , & April 10th, 1924 &, & 30 & $2-6$ & $2 \cdot 5$ \\
\hline Mactra stultorum & June 7 th, 1922 & Whitsand Bay & 18 & $3-4 \cdot 5$ & $3 \cdot 5$ \\
\hline Spisula elliptica & July $\quad 5$ th, 1922 & Queen's Ground & 281 & $1 \cdot 5-5 \cdot 5$ & $3 \cdot 5$ \\
\hline , & May 30th, 1923 & Bigbury Bay & 15 & $3-5 \cdot 5$ & $3 \cdot 5$ \\
\hline Lutraria elliptica & June 7 th, 1922 & Whitsand Bay & 30 & $2 \cdot 5-4 \cdot 5$ & $3 \cdot 5$ \\
\hline , & June 9th, 1922 & Bigbury Bay & 25 & $2 \cdot 5-4$ & $3 \cdot 5$ \\
\hline Lutraria oblonga & July $\quad 5$ th, 1922 & Queen's Ground & 56 & $3-7$ & $5 \cdot 0$ \\
\hline Cardium echinatum & July 10th, 1922 & Plymouth Sound & 10 & $2-3$ & $2 \cdot 25$ \\
\hline$"$ & July 24th, 1922 & Bigbury Bay & 25 & $2-12 \cdot 5$ & $4 \cdot \tilde{5}$ \\
\hline Cyprina islandica & July 24th, 1922 & Channel & 4 & $2-2 \cdot 5$ & $2 \cdot 5$ \\
\hline Mya truncata & June 26th, 1922 & Plymouth Sound & 12 & $2-4 \cdot 5$ & $3 \cdot 5$ \\
\hline Corbula gibba & June 26th, 1922 & , & 22 & $2 \cdot 5-4$ & $3 \cdot 0$ \\
\hline Solecurtus antiquatus & June 26th, 1922 & , & 8 & $3 \cdot 5-5$ & $4 \cdot 0$ \\
\hline Cultellus pellucidus & July 5 th, 1922 & , & 22 & $4-7$ & $5 \cdot 0$ \\
\hline , & July 10th, 1922 &, & 42 & $5-11$ & $7 \cdot 0$ \\
\hline , & Aug. 14th, 1922 & Channel & 101 & $4-10$ & $7 \cdot 0$ \\
\hline Ensis ensis* & June 26th, 1922 & Plymouth Sound & 12 & $6 \cdot 5-10$ & $8 \cdot 5$ \\
\hline , & June 20th, 1922 & Whitsand Bay & 35 & $5-14 \cdot 5 \quad 1$ & $10 \cdot 0$ \\
\hline Ensis arcuata* & June 26th, 1922 & Plymouth Sound & 20 & $5 \cdot 5-10 \cdot 5$ & $8 \cdot 5$ \\
\hline , & July 10th, 1922 & ., & 10 & $8-15$ & $11 \cdot 0$ \\
\hline
\end{tabular}

occasion, during a continuous series of visits to a particular locality, a large number of tiny individuals appear for the first time, this seems reasonable evidence of a recent fall of spat. The data given in the table are derived from such a series, and may thus be taken as indicating spatting at a date not far removed from the date of the hauls.

The food value of a stock derived from the same fall of spat is dependent on the length of time the individuals take to grow beyond a size useful to fishes. By visiting and revisiting a locality at intervals and noting the size of the individuals in the successive samples, it is possible to 
demonstrate increase in size, but, in practice, the results obtained are not always simple to interpret. There is no justification for assuming that the individuals of the same fall of spat will grow at the same rate over the whole area covered by the spat, even if that area is small, unless conditions are uniform. A rich growth of Syndosmya alba off Borough Island in Bigbury Bay is restricted by the nature of the bottom to a few square miles, and there is a localised area where the density of population is much greater than elsewhere. This area is also the home of a dense population of other lamellibranchs. If a line of stations be taken across the bed with the densest area in the centre of the line, the average size of the mollusc is greater where the numbers are fewer. Although this fact in itself is by no means a proof, it certainly may mean that growth has been checked at the densest area. In the second place, where spatting occurs over a prolonged time, repeated additions of small individuals will cause a depression of the modal value of a sample, and thus suggest a smaller growth than is actually the case. Thirdly, various causes of mortality also influence the average size of the sample. Probably, then, at best, successive sampling will give minimum values for growth. But in their relation to fisheries it is just these average conditions over a feeding ground which we wish to know, and by constant visits only ean we learn how each species reacts under the local conditions presented.

\section{Spisula Elliptica from Queen's Ground.}

At the entrance to Plymouth Sound a heavy fall of spat of Spisula elliptica settled on Queen's Ground during June, 1922. Owing to the proximity of buoys and land-marks, no great difficulty was experienced in returning at intervals to the same sampling station, so that it is assumed that the same stock was sampled on each occasion, with the reservations as above mentioned. Details of the hauls are shown in Table II.

\section{TABLE II.}

Spisula elliptica from Queen's Ground.

\begin{tabular}{|c|c|c|c|c|c|c|c|c|c|c|c|c|c|c|c|c|c|c|c|c|}
\hline \multirow{2}{*}{ DATE. } & \multirow{2}{*}{$\left|\begin{array}{c}\text { No. of } \\
\text { Dips of } \\
\text { Sampler }\end{array}\right|$} & \multicolumn{16}{|c|}{ No. of Specimens of length as under. } & \multirow{2}{*}{$\begin{array}{l}\text { Total } \\
\text { No. }\end{array}$} & \multirow{2}{*}{$\begin{array}{c}\text { No. } \\
\text { per } \\
1 \text { sq. } \\
\text { Mtre. }\end{array}$} & \multirow{2}{*}{ 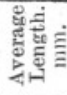 } \\
\hline & & 1.5 & 25 & 35 & $4: 5$ & $5 \cdot 5$ & 6.5 & $7 \cdot 5$ & $8 \cdot 5$ & $9: 5$ & $10 \cdot 5$ & $11 \cdot 5$ & $|12 \cdot 5|$ & 13.5 & $14 \cdot 5$ & $15 \div 5$ & 165 & & & \\
\hline 192 & & & & & & & & & & & & & & & & & & & & \\
\hline July 5th & 5 & 1 & 72 & 157 & 45 & $\begin{array}{r}6 \\
114\end{array}$ & $\overline{121}$ & $\overline{90}$ & $\overline{21}$ & - 2 & -1 & - & - & - & - & - & - & $\begin{array}{l}281 \\
415\end{array}$ & 562 & \\
\hline Sept. 19th & $\begin{array}{l}5 \\
2\end{array}$ & - & $\begin{array}{r}3 \\
-\end{array}$ & 21 & $\begin{array}{r}42 \\
-\end{array}$ & $\begin{array}{r}114 \\
1\end{array}$ & $\begin{array}{r}121 \\
4\end{array}$ & $\begin{array}{r}90 \\
6\end{array}$ & 13 & 20 & 24 & 7 & -2 & -1 & - & - & - & $\begin{array}{r}415 \\
78\end{array}$ & $\begin{array}{l}830 \\
390\end{array}$ & $\begin{array}{l}6 \cdot 18 \\
9 \cdot 59\end{array}$ \\
\hline Oet. 4 th & 5 & - & - & 1 & 2 & 2 & 4 & 9 & 17 & 40 & 58 & 46 & 23 & 4 & - & - & - & 207 & 414 & $10 \cdot 30$ \\
\hline $\begin{array}{l}\text { Dec. 7th } \\
1923\end{array}$ & 5 & - & - & - & - & - & - & - & 2 & 2 1 & 11 & 35 & 38 & 21 & 3 & - & - & 111 & 222 & $12 \cdot 13$ \\
\hline Feb. 20th & 6 & - & - & - & - & - & - & - & - & 5 & 6 & 6 & 8 & 6 & 12 & 10 & 1 & 54 & 90 & $13 \cdot 17$ \\
\hline
\end{tabular}


The successive samples having been taken under similar conditions, the number of specimens on each occasion may be accepted as an estimate of the density of population. It is possible, however, that on July 5th, 1922, a number of small individuals may have passed through the sieves used, in which case the calculated average size is somewhat higher than in reality, and the density of population under-estimated. The gradual decline in the number per 1 sq.-metre was accompanied by an increase in the number of empty but "fresh" shells. These latter were intact, with the two valves fully closed, and were often so similar in appearance to "living" individuals that it was considered necessary to open all the shells of a sample to ensure that only living individuals were being included in the count. The cause of this mortality was not obvious; relatively few had been bored by gasteropods, but starfishes may have been responsible, as, in previous years, Asterias has frequented Queen's Ground in numbers at the same period of the year.

If growth is considered in terms of length, the curves given in Figs. 1 and 2 clearly show that growth was most rapid during July, when in the 20 days from July 5th to July 25th, 1922, the average length rose from $3.44 \mathrm{~mm}$. to $6.18 \mathrm{~mm}$., which is a relative increase of $80 \%$ of the length on July 5th. During the 56 days following July 25th, growth in length was still marked, but less rapidly than previously, for it was a $55 \%$ increase in spite of a period of time nearly three times as long. Growth was slowest during the winter months; when from December 7th, 1922, until February 20th, 1923, the resultant increase for the 75 days was only $11 \%$ of the length on December 7 th.

In the discussion of growth as it affects the question of fish-food, it is weight rather than length which is the important factor for practical purposes. The weight $(\mathrm{W})$ of an individual is some function of the cube of its length $(\mathrm{L})$, and in order to determine, for this species, the relation between $\mathrm{W}$ and $\mathrm{L}^{3}, 889$ specimens from $2.5 \mathrm{~mm}$. to $16.5 \mathrm{~mm}$. in length were dried and weighed. The procedure adopted was to arrange the specimens in millimetre groups, and to treat each group as one unit. The total dry weight of each unit when divided by the number of specimens gave an average dry weight for one individual of that millimetre group. For the larger specimens, from $9.5 \mathrm{~mm}$. to $16.5 \mathrm{~mm}$., the soft parts were first removed from the shell, and the two dried and weighed separately, but this was not found practical for the smaller ones. Drying to a constant weight was accomplished in a water oven at $90^{\circ} \mathrm{C}$., and the dry weights were determined to $.001 \mathrm{grm}$. In the case of the smaller specimens drying was facilitated by first crushing them, during which operation, also, empty shells could be discovered and discarded. It must be pointed out, however, that the material had been preserved in spirit 
for a long time, so that the observed dry weights of soft parts, although comparable, are probably lower than in reality.

The results obtained by these experiments, together with values calculated from the suggested equation $\mathrm{W}=\cdot 00008 \mathrm{~L}^{3}$ are given in Table III (p. 538), and a comparison between the two sets of values of $\mathrm{W}$ will show that this relation of $\mathrm{W}$ to $\mathrm{L}^{3}$ is not improbable.

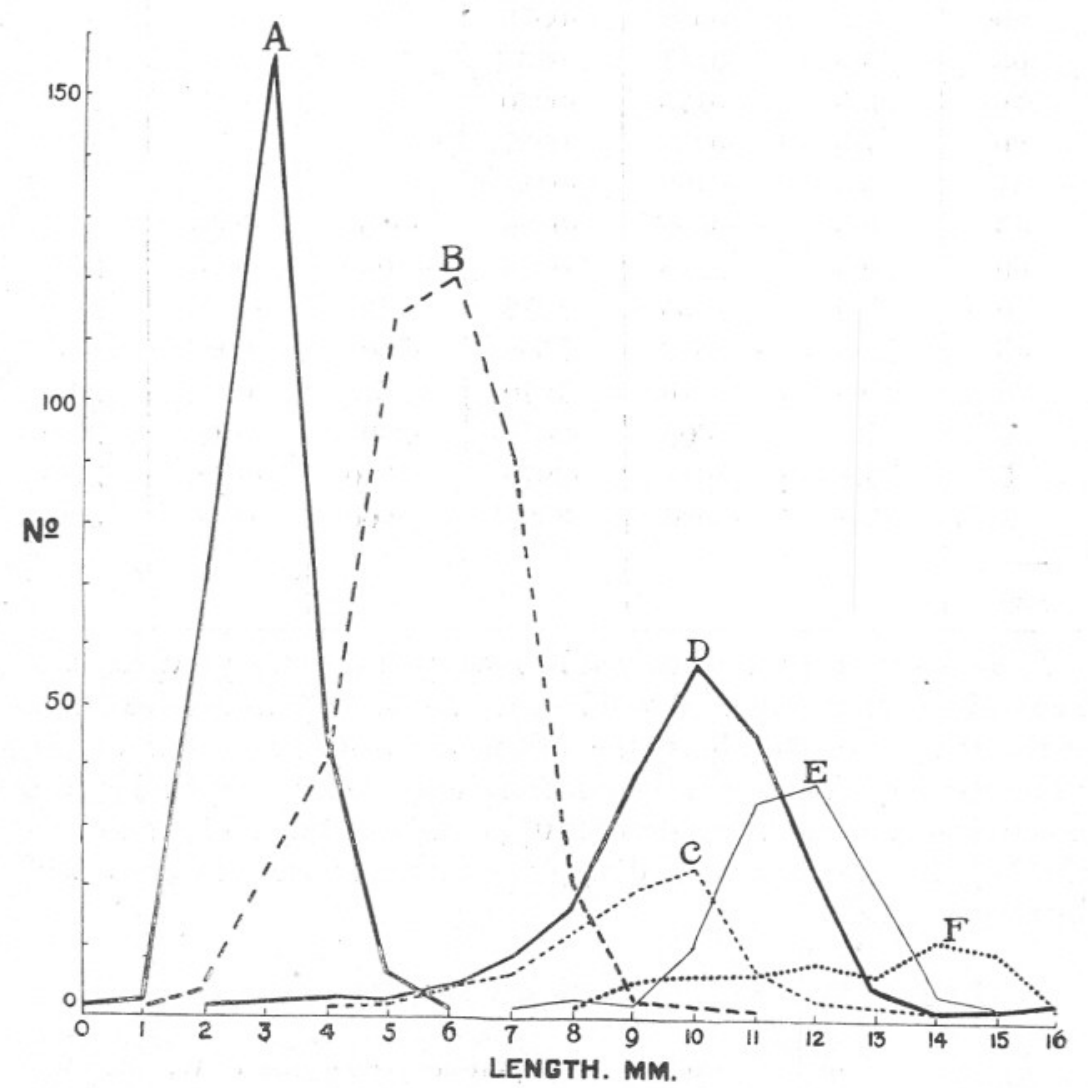

Fig. 1.-Spisula elliptica. Queen's Ground, 1922-23.
A. July 5th, 1922.
D. October 4th, 1922.
B. July 25 th, 1922 .
E. December 7th, 1922.
C. September 19th, 1922.
F. February 20th, 1923. 
TABLE III.-Spisula elliptica from Queen's Ground.

\begin{tabular}{|c|c|c|c|c|c|c|}
\hline $\begin{array}{c}\text { No. } \\
\text { of } \\
\text { specimens. }\end{array}$ & $\begin{array}{l}\begin{array}{l}\text { Length } \\
=\mathrm{L}\end{array} \\
\mathrm{mm} .\end{array}$ & $\begin{array}{c}\text { Average } \\
\text { dry weight } \\
\text { of } \\
\text { shells and } \\
\text { flesh } \\
=W \\
\text { grm. }\end{array}$ & $\begin{array}{c}\text { Calculated } \\
\text { values of } \\
W \text { from } \\
\text { equation } \\
W=\cdot 00008 L^{3} \\
\text { grm. }\end{array}$ & $\begin{array}{c}\text { Average } \\
\text { dry weight } \\
\text { of } \\
\text { shell only } \\
=W_{\mathrm{s}} \\
\text { grm. }\end{array}$ & $\begin{array}{c}\text { Average } \\
\text { dry weight } \\
\text { of } \\
\text { flesh only } \\
W_{f} \\
\text { grm. }\end{array}$ & $\begin{array}{c}\text { Values } \\
\text { of } \\
W_{\mathrm{s}} \\
\overline{W_{\mathrm{f}}}\end{array}$ \\
\hline 65 & $2 \cdot 5$ & .0016 & .0012 & - & - & - \\
\hline 140 & 3.5 & .0030 & .0034 & - & - & - \\
\hline 80 & $4 \cdot 5$ & .0062 & .0073 & - & - & - \\
\hline 103 & $5 \cdot 5$ & .0111 & .0133 & - & - & 一 \\
\hline 116 & $6 \cdot 5$ & .0175 & .0220 & - & - & - \\
\hline 90 & $7 \cdot 5$ & .0238 & .0337 & - & - & - \\
\hline 37 & 8.5 & .0469 & .0491 & - & - & - \\
\hline 45 & $9 \cdot 5$ & .0892 & .0686 & .0853 & .0039 & $21 \cdot 9$ \\
\hline 60 & 10.5 & $\cdot 1119$ & .0926 & $\cdot 1069$ & .0051 & $21 \cdot 0$ \\
\hline 70 & $11 \cdot 5$ & $\cdot 1355$ & $\cdot 1217$ & $\cdot 1291$ & .0064 & $20 \cdot 2$ \\
\hline 45 & 12.5 & $\cdot 1586$ & $\cdot 1562$ & $\cdot 1504$ & .0083 & $18 \cdot 1$ \\
\hline 26 & $13 \cdot 5$ & $\cdot 1970$ & $\cdot 1970$ & $\cdot 1878$ & .0093 & $20 \cdot 2$ \\
\hline 6 & $14 \cdot 5$ & $\cdot 2405$ & $\cdot 2439$ & $\cdot 2308$ & $\cdot 0100$ & $23 \cdot 0$ \\
\hline 5 & $15 \cdot 5$ & $\cdot 3044$ & $\cdot 2979$ & $\cdot 2920$ & $\cdot 0124$ & $24 \cdot 5$ \\
\hline 1 & $16 \cdot 5$ & $\cdot 3090$ & $\cdot 3594$ & $\cdot 3000$ & .0090 & $33 \cdot 3$ \\
\hline 889 & & & & & & \\
\hline
\end{tabular}

If the information thus derived be now applied to the previous statement of growth in length, it will be seen that an $80 \%$ increase in length in the 20 days from July 5 th to the 25 th, means a $470 \%$ increase in weight ; while the $55 \%$ increase in length from July 25th to September 19th involves an increase in weight of $270 \%$ of that of July 25th. Similarly, the $11 \%$ increase in length during the winter months, means a $28 \%$ increase in weight.

\section{TABLE IV.-Spisula elliptica from Queen's Ground.}

\begin{tabular}{|c|c|c|c|c|c|}
\hline $\begin{array}{l}\text { Date. } \\
1922\end{array}$ & $\begin{array}{l}\text { No. of dips } \\
\text { of } \\
\frac{1}{10} \mathrm{~m}^{2} \text { bottom } \\
\text { sampler. }\end{array}$ & $\begin{array}{c}\text { No. of } \\
\text { Individuals. }\end{array}$ & $\begin{array}{l}\text { Total } \\
\text { Dry-weight } \\
\text { grm. }\end{array}$ & $\begin{array}{l}\text { Dry weight } \\
\text { per. } 1 \text { sq. metre } \\
W_{1} ; W_{2} ; \text { etc. }\end{array}$ & $\begin{array}{l}\text { Values of } \\
\frac{W_{1}}{W_{1}} ; \frac{W_{2}}{W_{1}} ; \frac{W_{3}}{W} \\
\text { etc. }\end{array}$ \\
\hline July 5th & 5 & 281 & 1.029 & $2 \cdot 057$ & 1.0 \\
\hline July 25th & $\tilde{5}$ & 415 & $8 \cdot 854$ & $17 \cdot 707$ & $8 \cdot 6$ \\
\hline Sept. 19th & 2 & 78 & $5 \cdot 905$ & $29 \cdot 527$ & $14 \cdot 4$ \\
\hline Oct. 4th & 5 & 207 & $19 \cdot 338$ & $38 \cdot 675$ & $18 \cdot 9$ \\
\hline $\begin{array}{c}\text { Dec. } 7 \text { th } \\
1923\end{array}$ & 5 & 111 & $16 \cdot 249$ & $32 \cdot 498$ & $15 \cdot 8$ \\
\hline Feb. 20th & 6 & 54 & $10 \cdot 326$ & $17 \cdot 209$ & $8 \cdot 4$ \\
\hline
\end{tabular}


From the data given in Table III it is possible to deduce the total dry weight of the samples taken on the various dates (see Table IV), from which some idea can be obtained as to the relative fish-food value of the ground throughout the period of observation. The total dry weight thus rises to its maximum on October 4th, and then declines, but the residue in February is still over eight times as heavy as the July 5th stock from which it was derived, although numerically its density is less than one-fifth. Fig. 2 gives a graphic representation of the number of animals per 1 sq. metre, their total dry weight, and their average length, at each of the dates of sampling. It shows that although there was a reduction in num-

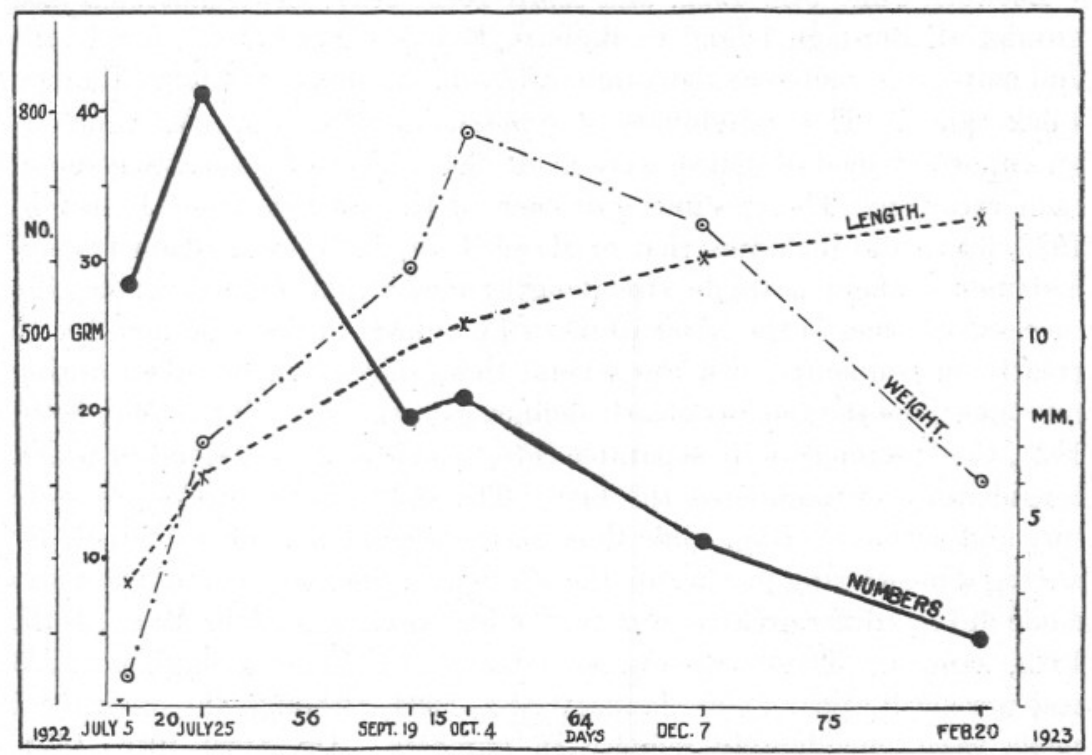

FIG. 2.-Spisula elliptica. Queen's Ground, 1922-23.

bers from 830 to 390 in the 56 days from July 25 th to September 19th, the total weight increased from 17.707 grm. to $29 \cdot 527 \mathrm{grm}$. But in the 75 days from December 7th, 1922, to February 20th, 1923, the drop in numbers from 222 to 90 resulted in a decrease in weight from $32 \cdot 498$ grm. to $17 \cdot 207 \mathrm{grm}$. It is therefore important to realise that mortality during the period of most rapid growth is more than compensated for by the growth of those that survive, whereas during the winter, when growth is slow, mortality may have a marked effect on the net weight of food.

\section{Syndosmya alba from BigBury Bay.}

It is well known that the shells of many lamellibranchs exhibit concentric rings which for a number of species have been shown to be the 
external expression of changes in the rate of growth. It is quite another matter to decide whether in a particular species, alternate acceleration in the summer and retardation in the winter in the growth rate produce a recognisable series of rings on the shell from which the age of the individual may be deduced. In some instances, experimental work suggests that, with certain reservations, such is definitely the case. For instance, Weymouth (1923) after a close study of the Pismo Clam (Tivela stultorum Mawe) states that during the winter pause in growth, a mark is formed at the margin of the shell, and from these annual marks the age may be determined accurately in the great majority of cases.

Between June 9th, 1922, and April 10th, 1924, the Syndosmya alba ground off Borough Island in Bigbury Bay (see Ford, 1923, for details and map), was visited at short intervals, and samples of the lamellibranch stock taken. The individuals of Syndosmya alba, a species which is an important food of plaice, were made the subject of close attention on each occasion. The specimens of each of the samples from June 9th, 1922, up to and including that of March 16th, 1923, were symmetrically distributed about a single size (length) mode, and, on the whole, the successive values of the latter while rising quickly at first, did not change greatly subsequently. Of the several thousands of shells taken during this time none showed any clearly defined growth ring. But on May 30th, 1923, the specimens were separable into two classes, the second of which considerably outnumbered the first. The shells of the first class were tiny and without a ring, while those of the second were characterised by having a brown ring just inside the white growing margin, and their size mode did not differ greatly from that of the specimens of the March 16th, 1923, sample. These two classes remained distinct throughout 1923 and were still apparent on January 31st, 1924, although the one-ringed shells were considerably reduced in numbers. On April 10th, 1924, three classes were obtained, one without ring, a second with one ring, and a third with two rings, the two-ringed class being the strongest numerically.

From these observations there seems the strongest possible justification for concluding that the 1922 stock assumed a growth ring between March 16th and May 30th, 1923, and a second between January 31st and April 10th, 1924, while the 1923 stock assumed a ring also between January 31st and April 10th, 1924. Moreover, these rings are a true index of the number of winters through which the individuals passed, and are most clearly marked on the shell. Boysen Jensen (1919, p. 11), however, states that in 1918 Syndosmya alba were observed to assume two rings in the year, so that apparently the experience of 1923-24 at Bigbury is not invariable.

The shells of the two-ringed class taken on April 10th. 1924, all showed 
a distinct difference between the width of the inner and the outer ring, the latter being the wider (see Pl. I, Fig. 3, bottom row). If, then, the ring itself is in reality the total winter growth, as seems likely, there was a relatively larger growth in the winter of 1923-24 than in that of 1922-23.

With this information it is possible to give a first summary of the composition of the stock for 1922, and the early part of 1924 . The stock from June, 1922, onwards consisted exclusively of individuals born in that year, and this was sufficiently great to form the bulk of the stock throughout 1923 and even until April, 1924. The brood of 1923 was small and not to be compared with that of the previous year, and very little of it was apparent in the following spring, nor was there a heavy successful spatting in early 1924. Finally, judging from the rate at which the 1922 stock was dying off latterly, it appeared likely, that unless a large new brood arose during 1924, the ground which was most rich in this food-species throughout 1922 and 1923 would become temporarily barren.

The above will now be discussed in rather more detail, commencing with the situation during 1922. From Table V (p. 542), it will be observed that the modal sizes of successive samples which are shown in bolder type, although in general they rise rapidly during June, July and August, and then remain tolerably steady from October to March, would not plot to a steady even curve. When more than one sample is shown for the same date (e.g. Hauls $4 \mathrm{a}, \mathrm{b}$ and $\mathrm{c}$ ), the one which is numerically the most dense is composed of specimens of lower modal value. Such samples were taken at different positions on the ground, and it was striking throughout the work, how a move of a few hundred yards altered both frequency and modal size value. There can be no question that there was at least one very localised area of great density, and a move from this spot meant an immediate decrease in numbers, with an eventual increase in size. It is not possible to say whether the lower modal value at the densest spot is due to stunted growth on account of overcrowding, or whether a great fall of spat had occurred there superimposed on a previous less dense but more widely spread population of the same year's spatting. Both may be true, but whatever the reason, the study of the growth rate is thereby rendered much more difficult, for successive hauls may not be exactly comparable unless there is certainty that they were taken at the same place. Utilising the data from stations believed to be within the area of maximum density, the modal length rose from $5.5 \mathrm{~mm}$. on June 9th, 1922, to $8.5 \mathrm{~mm}$. on July 24 th, a growth of $3.0 \mathrm{~mm}$. in 45 days; on the other hand, it remained practically stationary at $10 \cdot 5 \mathrm{~mm}$. from November 20th, 1922, until March 16th, 1923. But at stations outside the area of maximum density, the modal length reached $13.5 \mathrm{~mm}$. 
TABLE $\mathrm{V}$.

Syndosmya alba from Bigbury Bay.

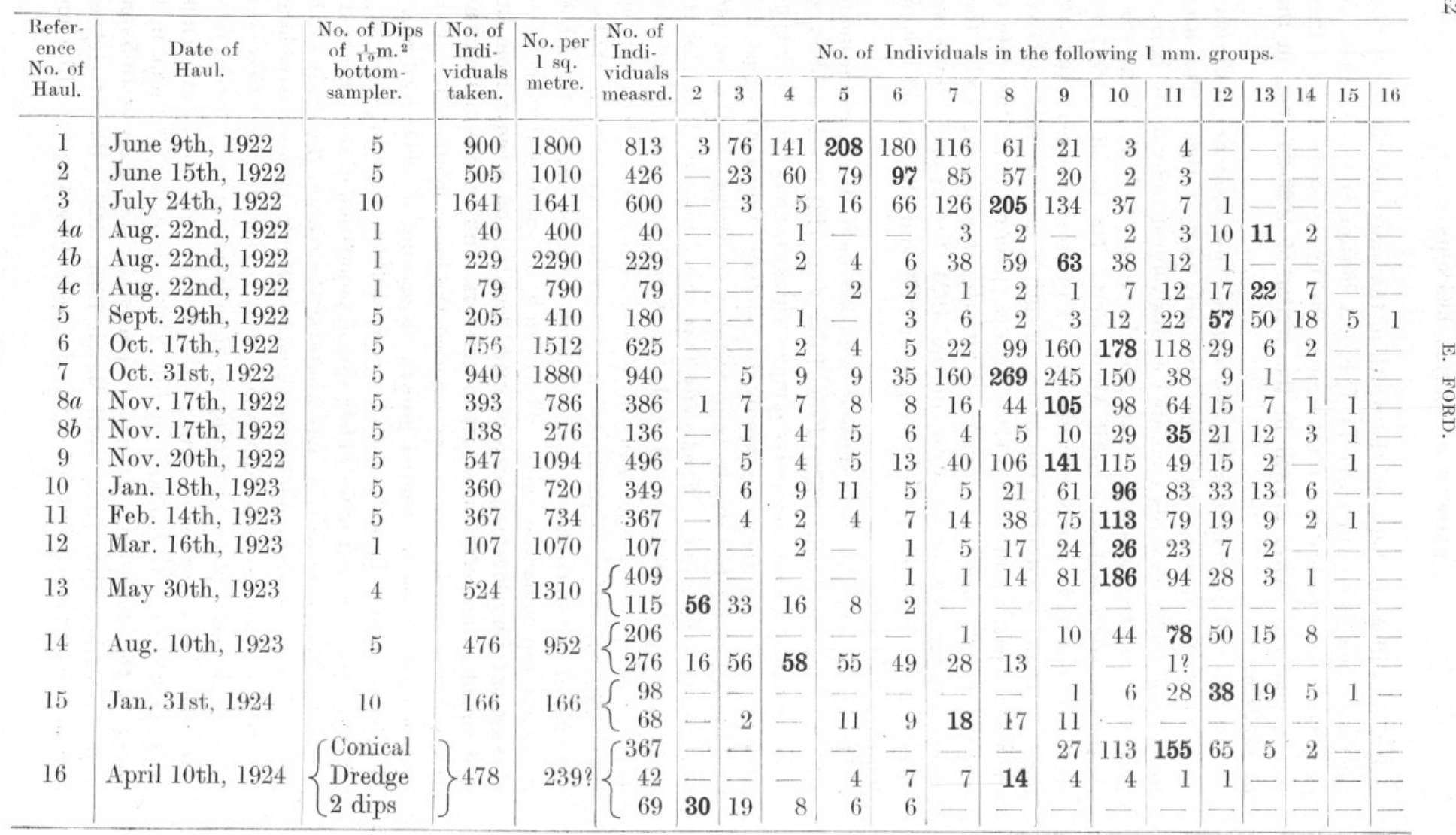


on August 22nd, 1922. If, as is possible, overcrowding results in stunted growth, the difference between the modes at a station within the densest area, and that at a station outside, is a measure of the effect of overcrowding. Thus, in August, shells closely crowded had grown to about $9.5 \mathrm{~mm}$. while those less densely packed had attained a length of $13.5 \mathrm{~mm}$.

Haul 13, taken on May 30th, 1923, contained specimens of two classes. There were a number of quite small ones, the $2 \mathrm{~mm}$. and $3 \mathrm{~mm}$. groups being the most frequent, and these were obviously a brood of the year 1923 . In addition, 409 specimens from $6.5 \mathrm{~mm}$. to $14.5 \mathrm{~mm}$. in length, with a mode at $10.5 \mathrm{~mm}$., exhibited a dark ring inside the margin of the shell. These were clearly the residue of the previous years' stock, and their weight undoubtedly formed the bulk of the stock on the day of sampling. By measuring the length* of the ring on each of the shells, it was possible to determine the amount of new growth which had taken place in 1923 . It was found that the modal length had increased from $9.5 \mathrm{~mm}$. to 10.5 mm. Now the ring was not completed on March 16th, 1923, so that between that date and May $30 \mathrm{th}$, the mode had risen by $1 \mathrm{~mm}$. The smallest shell was $6.5 \mathrm{~mm}$. in length and it had a ring $3.5 \mathrm{~m} . \mathrm{m}$ in length, while the largest was $14.5 \mathrm{~mm}$. long, with a ring less than $1 \mathrm{~mm}$. shorter. The ring, therefore, was found on shells of greatly varying lengths; was significant of a change in the growth rate, and independent of the size of the shell.

Haul 14, taken on August 10th, 1923, also contained specimens of two classes, one without a ring, the individuals of which were arranged about a mode of about $5 \mathrm{~mm}$. These were of the same class as those measuring from $2 \mathrm{~mm}$. to $3 \mathrm{~mm}$. on May 30th, 1923. The specimens of the second class were marked with one ring, their modal length being $11.5 \mathrm{~mm}$. The modal length of the rings was $10.5 \mathrm{~mm}$., so that there had been a new growth of $1 \mathrm{~mm}$.

On April 10th, 1924, three classes occurred. There were 69 individuals without a ring, representing a brood of 1924, 42 individuals with one ring, the residue of the 1923 broods, and 367 with two rings, the residue of the 1922 stock. The modal values for the three classes were $2.5 \mathrm{~mm}$., $8.5 \mathrm{~mm}$. and $11.5 \mathrm{~mm}$. respectively. Here again, the 1922 stock was still the ehief constituent of the population, and it will be instructive to determine, from the size of the successive rings, the size of the 1922 stock after the winter of 1922, and after that of 1923 . The 1922 rings varied in length from $4.5 \mathrm{~mm}$., to $13.5 \mathrm{~mm}$., the mean being at $9.01 \mathrm{~mm}$. The 1923 rings were from $8.5 \mathrm{~mm}$. to $14.5 \mathrm{~mm}$., with the mean at $11.02 \mathrm{~mm}$. Thus, shells of $9.01 \mathrm{~mm}$. at the end of their first winter in 1922, measured 11.02

* The "length" of the ring is its greatest antero-posterior dimension, See page 532 and Fig. 7, Plate III. 
mm., at the end of the second winter, and between January 31st, 1924, and April 10th, 1924, had increased a further amount of something under $1 \mathrm{~mm}$. Table VI is a correlation table for the first and second rings, from which the coefficient of correlation has been calculated to be .716 . The straight line from the equation $\mathrm{L}_{2}=6 \cdot 278+\cdot 526 \mathrm{~L}_{1}$ (where $\mathrm{L}_{2}$ and $\mathrm{L}_{1}$ are the length in $\mathrm{mm}$. of the second and first rings respectively), and the two graphs from experimental data are shown in Fig. 4.

The dry-weight of specimens of lengths from $2.5 \mathrm{~mm}$. to $15 \mathrm{~mm}$. were determined as for Spisula elliptica (see page 536), and are shown in Table VII (p. 546). For this species the equation $W=\cdot 00003 \mathrm{~L}^{3}$ is a fair approximation, and it has been used to calculate the dry-weights of samples

\section{TABLE VI.}

Syndosmya alba from Bigbury Bay, April 10th, 1924.

\begin{tabular}{|c|c|c|c|c|c|c|c|c|c|c|}
\hline & & & & 2nd & Ring $\mathrm{m}$ & & & & & \\
\hline & & $8 \cdot 5$ & $9 \cdot 5$ & $10 \cdot 5$ & $11 \cdot 5$ & $12 \cdot 5$ & 13.5 & $14 \cdot 5$ & Total & Mean. \\
\hline & $4 \cdot 5$ & - & 1 & - & - & - & - & - & 1 & $9 \cdot 50$ \\
\hline & $5 \cdot 5$ & - & 1. & 1 & - & - & - & - & 2 & $10 \cdot 00$ \\
\hline & 6.5 & 1 & 8 & 2 & 2 & - & - & - & 13 & $9 \cdot 88$ \\
\hline 1st & $7 \cdot 5$ & - & 19 & 28 & 8 & 2 & - & - & 57 & $10 \cdot 38$ \\
\hline ring & 8.5 & - & 21 & 55 & 34 & 4 & - & - & 114 & $10 \cdot 65$ \\
\hline $\mathrm{mm}$. & $9 \cdot 5$ & - & 1 & 39 & 57 & 6 & - & - & 103 & $11 \cdot 08$ \\
\hline & $10 \cdot 5$ & - & - & 3 & 35 & 19 & 1 & - & 58 & $11 \cdot 81$ \\
\hline & 11.5 & - & - & - & 3 & 9 & 2 & 1 & 15 & $12 \cdot 57$ \\
\hline & 12.5 & - & - & - & - & 2 & 1 & - & 3 & $12 \cdot 83$ \\
\hline & $13 \cdot 5$ & - & - & - & - & - & 一 & 1 & 1 & 14.50 \\
\hline & & 1 & 51 & 128 & 139 & 42 & 4 & 2 & 367 & \\
\hline b & & $6 \cdot 50$ & $7 \cdot 70$ & $8 \cdot 60$ & $9 \cdot 41$ & $\cdot 38$ & 50 & 12.50 & & \\
\hline
\end{tabular}

on various dates, shown in Table VIII (p. 546). From the figures abtained it is seen that the 1922 stock was the predominant element throughout, and even at the beginning of the summer growth in 1924, it formed over ninetenths of the weight of the whole stock. It is impossible to state the reasons for this predominence of the year class 1922. Undoubtedly there was a great and successful fall of spat in the spring of that year, and the brood grew and survived, and clearly no similar survival could have occurred in 1921. If 1923 and early 1924 were good breeding years, the spat which fell did not survive in quantity in the area already populated by the dense 1922 stock. It is possible that elsewhere the spat may have settled and flourished, but has escaped detection. On the other hand, little spatting may have occurred at all. Boysen Jensen $(1919$, p. 13) 
states that in Danish waters broods of Syndosmya alba appear about every second year.

The total dry-weight per $1 \mathrm{sq}$. metre was at its maximum in May, 1923, and then a decline became apparent. It is disappointing not to be able to give figures for April 10th, 1924, in order that the prospects for 1924 might be known more definitely, but owing to bad weather-conditions it was impossible to use the bottom-sampler satisfactorily on that occasion, and the only way to get a sample at all was by risking a conical dredge.

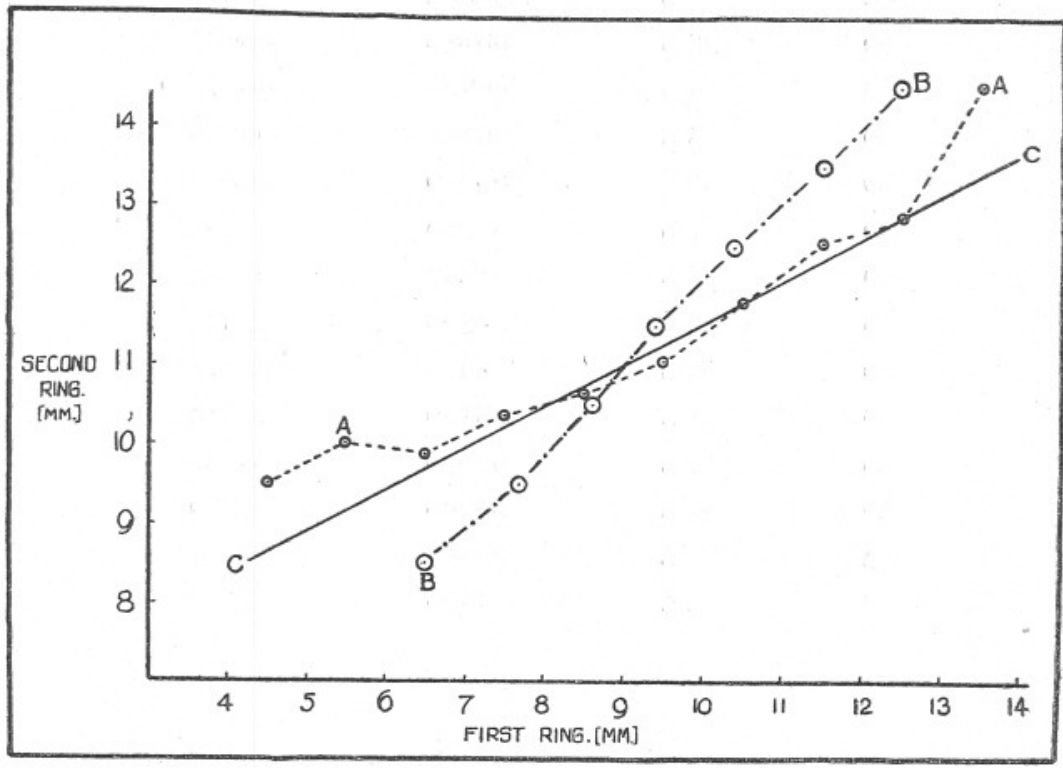

Fra. 4.-Syndosmya alba. Bigbury Bay, April 10th, 1924.
AA. Observed first ring and mean second ring.
BB. Observed second ring and mean first ring.
CC. From equation $\mathrm{L}_{2}=6 \cdot 278+\cdot 526 \mathrm{~L}_{1}$.

Living individuals were vastly outnumbered by freshly-dead shells, many of which on the evidence of their rings had died during the winter of 1923-24. In a previous paper (Ford, 1923, p. 191) it was shown that one dip of the conical dredge on this same ground was then equivalent to ten of the bottom-sampler, so that if we regard the two hauls of the conical dredge on April 10th, 1924, as equivalent to twenty dips of the sampler, the number per $1 \mathrm{sq}$. metre would be 478 which is 239 , having a total dry-weight of $8.49 \mathrm{grm}$. This weight is about one-third of that on August 10th, 1924. From these figures, then, it seems fair to predict that the ground will be poor in condition during the spring and early summer 
TABLE VII.

Syndosmya alba from Bigbury Bay.

\begin{tabular}{|c|c|c|c|}
\hline $\begin{array}{c}\text { No. } \\
\text { of } \\
\text { specimens. }\end{array}$ & $\begin{array}{l}\text { Length } \\
=\mathrm{L} \\
\text { mm. }\end{array}$ & $\begin{array}{c}\text { Average } \\
\text { dry-weight } \\
\text { of } \\
\text { shell and } \\
\text { flesh } \\
=\text { Wgrm. }\end{array}$ & $\begin{array}{c}\text { Calculated } \\
\text { Values } \\
\begin{array}{c}W=\cdot 00003 \mathrm{~L} \\
\text { grm. }\end{array}\end{array}$ \\
\hline 100 & $2 \cdot 5$ & .00065 & .00047 \\
\hline 100 & $3 \cdot 5$ & .00160 & .00129 \\
\hline 50 & $4 \cdot 5$ & .00238 & .00273 \\
\hline 50 & $5 \cdot 5$ & .00408 & .00499 \\
\hline 50 & $6 \cdot 5$ & .00620 & .00824 \\
\hline 50 & $7 \cdot 5$ & $\cdot 01260$ & .01266 \\
\hline 50. & $8 \cdot 5$ & $\cdot 01562$ & .01842 \\
\hline 50 & $9 \cdot 5$ & $\cdot 02200$ & .02572 \\
\hline 50 & $10 \cdot 5$ & $\cdot 04038$ & $\cdot 03474$ \\
\hline 50 & $11 \cdot 5$ & .05180 & .04563 \\
\hline 50 & $12 \cdot 5$ & .06620 & .05859 \\
\hline 50 & $13 \cdot 5$ & $\cdot 07960$ & $\cdot 07380$ \\
\hline 15 & $14 \cdot 5$ & .09667 & .09147 \\
\hline 2 & $15 \cdot 5$ & $\cdot 11900$ & $\cdot 11172$ \\
\hline
\end{tabular}

TABLE VIII.

Syndosmya alba from Bigbury Bay.

\begin{tabular}{|c|c|c|c|c|c|c|c|c|c|c|}
\hline \multirow{2}{*}{$\begin{array}{l}\text { Refer- } \\
\text { ence No. } \\
\text { of } \\
\text { Haul. }\end{array}$} & \multirow[t]{2}{*}{ Date of Haul. } & \multirow{2}{*}{$\begin{array}{c}\text { No. } \\
\text { of } \\
\text { Indi- } \\
\text { viduals. }\end{array}$} & \multirow{2}{*}{$\begin{array}{c}\text { Total } \\
\text { Dry } \\
\text { weight. } \\
\text { grm. }\end{array}$} & \multicolumn{3}{|c|}{$\begin{array}{l}\text { Percentage of Total } \\
\text { Dry-weight for the } \\
\text { following :- }\end{array}$} & \multirow{2}{*}{$\begin{array}{c}\text { No. of } \\
\text { Indi- } \\
\text { viduals } \\
\text { per } \\
1 \text { sq. } \\
\text { metre. }\end{array}$} & \multirow{2}{*}{$\begin{array}{c}\text { Total } \\
\text { Dry- } \\
\text { weight } \\
\text { per } \\
1 \mathrm{sq} . \\
\text { metre } \\
\text { grm. }\end{array}$} & \multicolumn{2}{|c|}{$\begin{array}{l}\text { Dry-weight per } \\
1 \text { sq. metre of } \\
\text { following :- }\end{array}$} \\
\hline & & & & $\begin{array}{l}1922 \\
\text { stock. }\end{array}$ & $\begin{array}{l}1923 \\
\text { stock. }\end{array}$ & $\begin{array}{l}1924 \\
\text { stock. }\end{array}$ & & & $\begin{array}{c}1922 \\
\text { Stock }\end{array}$ & $\begin{array}{c}1923 \\
\text { Stock. }\end{array}$ \\
\hline 1 & June 9th, 1922 & 813 & $6 \cdot 42$ & 100 & - & - & 1800 & $14 \cdot 20$ & $14 \cdot 20$ & - \\
\hline 3 & July 24 th, 1922 & 600 & $11 \cdot 12$ & 100 & - & - & 1641 & $30 \cdot 30$ & $30 \cdot 30$ & - \\
\hline 9 & Nov. 20th,1922 & 496 & $13 \cdot 60$ & 100 & - & - & 1094 & $30 \cdot 06$ & $30 \cdot 06$ & - \\
\hline 13 & May 30 th, 1923 & $\begin{array}{l}409 \\
115\end{array}$ & $\left.\begin{array}{r}15 \cdot 09 \\
.17\end{array}\right\}$ & $98 \cdot 9$ & $1 \cdot 1$ & - & 1310 & $38 \cdot 13$ & $37 \cdot 71$ & $\cdot 42$ \\
\hline 14 & Aug.10th,1923 & $\begin{array}{l}206 \\
276\end{array}$ & $\left.\begin{array}{r}10 \cdot 13 \\
1.61\end{array}\right\}$ & $86 \cdot 3$ & $13 \cdot 7$ & - & 952 & $23 \cdot 46$ & $20 \cdot 22$ & $3 \cdot 21$ \\
\hline 16 & April 10th,1924 & $\begin{array}{r}367 \\
42 \\
69\end{array}$ & $\left.\begin{array}{r}16 \cdot 07 \\
.77 \\
\cdot 14\end{array}\right\}$ & $94 \cdot 6$ & $4 \cdot 5$ & $\cdot 8$ & & Not av & ailable. & \\
\hline
\end{tabular}


of 1924, and unless new broods appear and flourish during the year, it will become relatively barren by the winter of 1924-25.

If the total dry-weight of a number of specimens be calculated, as well as the weight at the lengths at which their winter-rings were assumed, the results are a measure of the increase in weight for the successive periods. Thus, the 409 specimens of Haul 13 on May 30th, 1923, weighed $11.83 \mathrm{grm}$. at the end of their first winter (1922-23), and $15.09 \mathrm{grm}$. in the following May, the proportion being $1: 1 \cdot 27$. The 206 specimens of August 10th, 1923, weighed $6.98 \mathrm{grm}$. at the end of the winter of 1922-23, and $10.13 \mathrm{grm}$. in the following August, the proportion being $1: 1 \cdot 45$. The difference between the ratios naturally expresses the growth from May to August.

The 478 specimens of the 1922-year class taken on April 10th, 1924, weighed $8.46 \mathrm{grm}$. at the end of the winter of $1922-23 ; 15.06 \mathrm{grm}$. at the end of the winter of 1923-24; and 16.07 grm. on April 10th, 1924. These values are in the proportion of $1: 1 \cdot 78: 1 \cdot 90$.

\section{Cardium echinatum from Bigbury Bay.}

The hauls on the Bigbury Bay ground also contained numbers of the spiny cockle, Cardium echinatum, and on similar evidence to that for Syndosmya alba, this species also produced winter growth-rings (see Pl. III, Fig. 5) at the same period of the year. That is, a brood of cockles spatted in the spring of 1922, assumed one ring in the spring of 1923, and a second in the spring of 1924. Plate II, Fig. $6 \mathrm{~A}$ and $\mathrm{B}$ of one valve of the same specimen photographed by reflected light and transmitted light respectively, illustrate the sharply-marked change in shell thickness coinciding with the rings.

By measuring the length of the rings and the total length of shells taken on various dates, information was obtained on the variation in length of individuals at the end of the first and second winters. Such information is important in its relation to the value of the species as fishfood, for the spiny cockle can grow to a size certainly beyond that suitable to flat fish of marketable size.

From Table IX (p. 548) it is seen that the length of the shell at the formation of the 1922-23 winter-ring varied from 9 to $24 \mathrm{~mm}$., with the majority of individuals between $15 \mathrm{~mm}$. and $19 \mathrm{~mm}$. in length, and the average length $18.2 \mathrm{~mm}$. This size must be near the limit of the capacity of flat fish, so that it follows that soon after the commencement of the summer growth for 1923, spiny cockles on the Bigbury Bed spatted in the spring of 1922, were becoming less and less available as food owing to their exceeding the size limit in gradually increasing numbers. There is, therefore, a big difference in the food-value of spiny cockles 
to fishes, from that of Syndosyma alba. In the case of the latter, a great fall of spat in the spring which can grow and flourish, may form a valuable food stock for fish for two years after spatting, whereas a successful spatting of the cockle in the spring, although it may give a much heavier yield by weight of fish food for the current year, will be unavailable owing to its rapid growth soon after the commencement of the next year's growth. If, however, it is possible that the spiny cockle can produce broods late in the summer, when the growth for the year is practically finished, then, of course, this may be of suitable size for fishes during the next season or part of it. I have no evidence, however, from the present material, that extensive late summer spatting may occur.

Sufficient material was not available for the determination of dryweights corresponding to a series of $1 \mathrm{~mm}$. length-groups as was done for

TABLE IX.

Cardium echinatum from Bigbury Bay.

\begin{tabular}{|c|c|c|c|c|c|c|}
\hline \multirow[b]{2}{*}{ Date. } & \multicolumn{3}{|c|}{$\begin{array}{l}\text { Number of specimens having } \\
\text { first winter-ring at following } \\
\text { length in } \mathrm{mm} \text {. }\end{array}$} & \multirow{2}{*}{$\begin{array}{c}\text { Range } \\
\text { in } \\
\text { length. } \\
\mathrm{mm} .\end{array}$} & \multirow{2}{*}{$\begin{array}{l}\text { Total No. } \\
\text { of } \\
\text { specimens. }\end{array}$} & \multirow{2}{*}{$\begin{array}{c}\text { Average } \\
\text { length at } \\
\text { formation of } \\
\text { Ist ring. } \\
\text { mm. }\end{array}$} \\
\hline & $9-14$ & $15-19$ & $20-24$ & & & \\
\hline May 30th, 1923 & 9 & 20 & 16 & $9-24$ & 45 & $18 \cdot 4$ \\
\hline April 10th, 1924 & 8 & 36 & 16 & $12-22$ & 60 & $18 \cdot 0$ \\
\hline May 7 th, 1924 & 6 & 32 & 10 & $13-22$ & 48 & $18 \cdot 1$ \\
\hline Totals & 23 & 88 & 42 & $9-24$ & 153 & $18 \cdot 2$ \\
\hline
\end{tabular}

Syndosmya alba, but ten specimens of an average length of $16.5 \mathrm{~mm}$. produced 4.984 grm. of dried shell and flesh, while ten specimens of 19.5 mm. average length produced $8.025 \mathrm{grm}$. of dried shell and flesh. The twenty individuals were from hauls in late autumn of 1922 in which Syndosmya alba of a similar age were present, of an average length of $10.5 \mathrm{~mm}$. and an average dry-weight of $0.03 \mathrm{grm}$. The ten cockles of $16.5 \mathrm{~mm}$. were thus by dry-w ight equivalent to 154 average Syndosmya, and the ten at $19.5 \mathrm{~mm}$. to 267 Syndosmya towards the end of the growth period for 1922. The dry-weight of flesh only for the $16.5 \mathrm{~mm}$. and the $19.5 \mathrm{~mm}$. cockles were $0.376 \mathrm{grm}$. and $.505 \mathrm{grm}$. respectively, which are .075 and $\cdot 063$ of the total dry-weight.

The ring of the winter 1923-24 although recognisable in the majority of shells taken both on April 10.h and May 7th, 1924, did not appear so clearly marked as the first ring. Reference has previously been made to a difference between the width of the actual ring for the 1922-23 
ring and the 1923-24 ring in Syndosmya, the latter being the broader, and it may be that the experience in the cockle is due to the same cause. Forty-five shells taken on May 7 th, 1924, showing a first ring varying from $13 \mathrm{~mm}$. to $22 \mathrm{~mm}$., and an average of $18.1 \mathrm{~mm}$., had a second ring ranging from $29 \mathrm{~mm}$. to $35 \mathrm{~mm}$., of an average length of $32 \cdot 3 \mathrm{~mm}$. The average 1922 growth was therefore $18.1 \mathrm{~mm}$., and that of $1923,14.2 \mathrm{~mm}$., which are in the proportion of $1: 0 \cdot 78$. The corresponding ratio for Syndosmya was $9 \cdot 01: 2.01$ which is $1: 0 \cdot 22$; suggesting that the second year's growth of the cockle was relatively greater than in Syndosmya on the same ground.

\section{Spisula solida from Start Bay.}

On November 19th, 1923, a total of 1862 living Spisula solida were collected from nine stations along a line following the shore in Start Bay for about four sea-miles from off Street Head towards Hallsands, at a depth of ten metres. Spisula solida was practically the only species represented in a bottom soil consisting for the most part of coarse waterworn gravel and stones. Two dips of the $\frac{1}{10}$ sq. metre bottom-sampler were taken at each station, and at six positions the numbers taken indicated a population of well over 1000 per sq. metre. The actual density probably exceeded this figure, for the sampler does not work ideally in so coarse a soil. At most stations the shells were one inch or more in length, so that for at least three miles they must have been extremely closely packed.

All the shells were most distinctly marked with rings, and it is the significance of these rings which forms the subject of immediate interest. It is to be regretted that, from lack of sufficient information, it is not at present possible to state whether or no they are a reliable index of age. There can be no doubt, however, that the rings are the result of disturbance in growth, for the examination of any shell by transmitted light shows at once a distinct reduction in the thickness of shell at each of the rings, as well as a difference in thickness of the successive zones between the rings. Plate III, Fig. 7 is a fair illustration of this. Superficially, then, these rings in Spisula solida are identical in appearance to those which in the species discussed on preceding pages have been shown to be annual in formation. But, if, in the event of evidence being forthcoming that one or more of the series of these so similar rings may be due to disturbances in growth, which are not necessarily regularly periodic, it would appear hopeless to attempt to deduce the age of the shell. Yet, after a great number of measurements of successive rings on the majority of the 1862 shells, I feel convinced that much useful information can be derived from the arrangement of the rings, whatever may have been the cause of their formation. 
It will be convenient to commence with a statement of several facts and with the conclusions which may be drawn from them :-

1. The number of rings on a single shell varied from 1 to certainly 7 and possibly 8 .

2. For each station it was possible, by inspection, to recognise at least one definable arrangement of a given number of rings, and to pick out a good number of specimens unquestionably exhibiting this arrangement of rings.

2a. Usually one typical arrangement of rings predominated at each station.

$2 b$. The type for one station frequently differed from that of the next.

2c. The same type may be represented on more than one station.

Several conclusions may be drawn from the facts set out under heading 2. The main observation that a good number of specimens at the same station showed the same number of rings arranged in a similar manner would seem to justify the conclusion that these specimens had undergone the same series of disturbances in growth. If the same type may be represented on more than one station, then it is also reasonable to conclude that this same series of disturbances has reacted on the individuals at more than one station. But, as the type on one station may differ from that of the next, either the population of the several stations have undergone different parts of a series of disturbances which occurred generally over the whole area, or else there were independent and different series of disturbances at different stations.

3. The shells of a given type of ring-arrangement on the same station are of a similar size.

3a. Stations on which the same type of shell occurs may differ very much in the average length of the shells of that type.

$3 \mathrm{~b}$. The average length of shells of a type with few rings on one station may exceed that of shells of a type with a larger number of rings at a second station.

If the shells of a given type on the same station are of a similar size, then, following on the conclusions drawn from heading 2 , it may be said that the resultant effect of a series of disturbances on a station may be expressed by the average size of the shells of that type. Observation 3a thus shows that stations must differ in the resultant effect of the same 
series of disturbances, while definite data on $3 \mathrm{~b}$ will give the degree to which stations may differ.

Now if the average size of specimens having say six rings differs at the several stations, and may even be exceeded by that of three-ringed shells, it will be a matter of some difficulty to arrive at a reasonable estimate of the quantity of fish-food available on the whole feeding ground. Even if it can be proved that the rings on the shells are annual in formation, and are thus expressive of age, so that the relative growth

TABLE $\mathrm{X}$.

Spisula Solida from Start Bay, November, 1923.

\begin{tabular}{|c|c|c|c|c|c|c|c|c|c|c|c|}
\hline \multirow[t]{2}{*}{$\begin{array}{l}\text { Ref. No. } \\
\text { of } \\
\text { station. }\end{array}$} & \multirow{2}{*}{$\mid \begin{array}{c}\text { No. } \\
\text { Dips } \\
\text { of } \\
16 \mathrm{~m}^{2}{ }^{2} \\
\text { sampler. }\end{array}$} & \multirow[t]{2}{*}{$\begin{array}{l}\text { Total } \\
\text { No. of } \\
\text { shells. }\end{array}$} & \multirow[t]{2}{*}{$\begin{array}{l}\text { No. of } \\
\text { rings on } \\
\text { shells. }\end{array}$} & \multirow[t]{2}{*}{$\begin{array}{l}\text { No. of } \\
\text { shells. }\end{array}$} & \multicolumn{3}{|c|}{$\begin{array}{l}\text { Average length in mm. of } \\
\text { shell at formation of the } \\
\text { following rings. }\end{array}$} & \multirow{2}{*}{$\begin{array}{c}\text { Average } \\
\text { total } \\
\text { length. } \\
\text { mm. }\end{array}$} & \multicolumn{3}{|c|}{$\begin{array}{c}\text { Growth between succes- } \\
\text { sive rings. } \\
\text { mm. }\end{array}$} \\
\hline & & & & & 1 & 2 & 3 & & $1-2$ & $2-3$ & $\begin{array}{l}\text { 3-total } \\
\text { length. }\end{array}$ \\
\hline 6 & 2 & 153 & 6 & 107 & $7 \cdot 68$ & $15 \cdot 83$ & $26 \cdot 07$ & $30 \cdot 83$ & $8 \cdot 14$ & $10 \cdot 25$ & $4 \cdot 76$ \\
\hline 51 & 2 & 217 & 6 & 127 & 6.95 & $14 \cdot 09$ & 21.97 & 28.93 & $7 \cdot 14$ & $7 \cdot 88$ & $6 \cdot 96$ \\
\hline 52 & 2 & 234 & 6 & 128 & 7.01 & $14 \cdot 05$ & $22 \cdot 37$ & $27 \cdot 91$ & $7 \cdot 05$ & $8 \cdot 31$ & $5 \cdot 55$ \\
\hline 53 & 2 & 390 & 6 & 303 & $7 \cdot 09$ & $13 \cdot 50$ & $20 \cdot 20$ & $26 \cdot 37$ & $6 \cdot 41$ & $6 \cdot 69$ & $6 \cdot 18$ \\
\hline 55 & 2 & 259 & 6 & 195 & $7 \cdot 61$ & $14 \cdot 74$ & $23 \cdot 86$ & $32 \cdot 16$ & $7 \cdot 13$ & $9 \cdot 12$ & $8 \cdot 29$ \\
\hline 50 & 2 & 73 & 5 & 19 & $5 \cdot 66$ & $21 \cdot 24$ & $26 \cdot 76$ & $34 \cdot 50$ & $15 \cdot 58$ & $5 \cdot 53$ & $7 \cdot 74$ \\
\hline $50 \mathrm{~A}$ & 2 & 239 & 5 & 20 & $6 \cdot 30$ & $19 \cdot 75$ & $25 \cdot 95$ & $33 \cdot 00$ & 13 & $6 \cdot 20$ & $7 \cdot 05$ \\
\hline 51 & 2 & 217 & 5 & 31 & $5 \cdot 73$ & $15 \cdot 89$ & ? & $26 \cdot 98$ & $10 \cdot 16$ & ? & ? \\
\hline 52 & 2 & 234 & 5 & 32 & $5 \cdot 47$ & $18 \cdot 63$ & $23 \cdot 59$ & $30 \cdot 19$ & $13 \cdot 16$ & $4 \cdot 97$ & $6 \cdot 59$ \\
\hline 55 & 2 & 259 & 5 & 10 & $5 \cdot 40$ & $17 \cdot 90$ & $22 \cdot 90$ & $30 \cdot 40$ & $12 \cdot 50$ & 5.00 & $7 \cdot 50$ \\
\hline $50 \mathrm{~A}$ & 2 & 239 & 4 & 16 & $7 \cdot 50$ & $22 \cdot 62$ & $29 \cdot 62$ & $34 \cdot 38$ & $15 \cdot 11$ & $7 \cdot 00$ & $4 \cdot 76$ \\
\hline 50 & 2 & 73 & 3 & 27 & $11 \cdot 60$ & $18 \cdot 20$ & $25 \cdot 98$ & $30 \cdot 17$ & $6 \cdot 59$ & $7 \cdot 78$ & $4 \cdot 19$ \\
\hline $50 \mathrm{~A}$ & 2 & 239 & 3 & 67 & $12 \cdot 04$ & $18 \cdot 39$ & $25 \cdot 53$ & $28 \cdot 22$ & $6 \cdot 35$ & $7 \cdot 14$ & $2 \cdot 69$ \\
\hline 52 & 2 & 234 & 3 & 17 & $10 \cdot 73$ & $15 \cdot 47$ & $24 \cdot 38$ & $27 \cdot 03$ & $4 \cdot 73$ & 8.91 & $3 \cdot 65$ \\
\hline 54 & 2 & 295 & 3 & 279 & $10 \cdot 69$ & $15 \cdot 96$ & $\begin{array}{l}\text { (close to } \\
\text { margin) }\end{array}$ & $23 \cdot 43$ & $5 \cdot 27$ & $?$ & $?$ \\
\hline 6 & 2 & & & 17 & & & & & $\begin{array}{c}\text { 1-total } \\
\text { length. } \\
9 \cdot 53\end{array}$ & & \\
\hline 50 & $\overline{2}$ & $\begin{array}{r}735 \\
73\end{array}$ & 1 & 14 & $\begin{array}{r}11.02 \\
8.36\end{array}$ & - & - & $\begin{array}{l}21 \cdot 13 \\
17 \cdot 93\end{array}$ & $9 \cdot 57$ & - & - \\
\hline $50 \mathrm{~A}$ & 2 & 239 & 1 & 50 & 8.90 & - & - & $17 \cdot 14$ & $8 \cdot 24$ & - & - \\
\hline 51 & 2 & 217 & 1 & 24 & $7 \cdot 67$ & - & - & $15.83^{\circ}$ & 817 & - & - \\
\hline 55 & 2 & 259 & 1 & 16 & $10 \cdot 75$ & - & - & $17 \cdot 81$ & $7 \cdot 06$ & - & - \\
\hline
\end{tabular}

in the successive years may be determined, the data derived from a sample of Spisula solida is only applicable to the position on the area from which the sample was taken, and may not in any way give a fair estimate of the general conditions.

A six-ringed type of shell was the most general in distribution and the most numerous. The first, second and third rings were well separated, but the fourth to the sixth were relatively close up to the third, giving the effect of four fairly evenly spaced rings close to the margin of the shell (see Pl. I, Fig. 8 F). An inspection of Table $\mathrm{X}$ will show that this type 
was the dominant one except on Station 54 where three-ringed individuals were present almost to the exclusion of others; the variation of the average size at the different stations will also be noticed, as well as the facts that three-ringed shells on Station 50 exceeded in size the six-ringed ones on Stations 51, 52 and 53.

Table $\mathrm{X}$ is not intended as a complete record of the specimens from each station, but as a means of showing the variation from station to

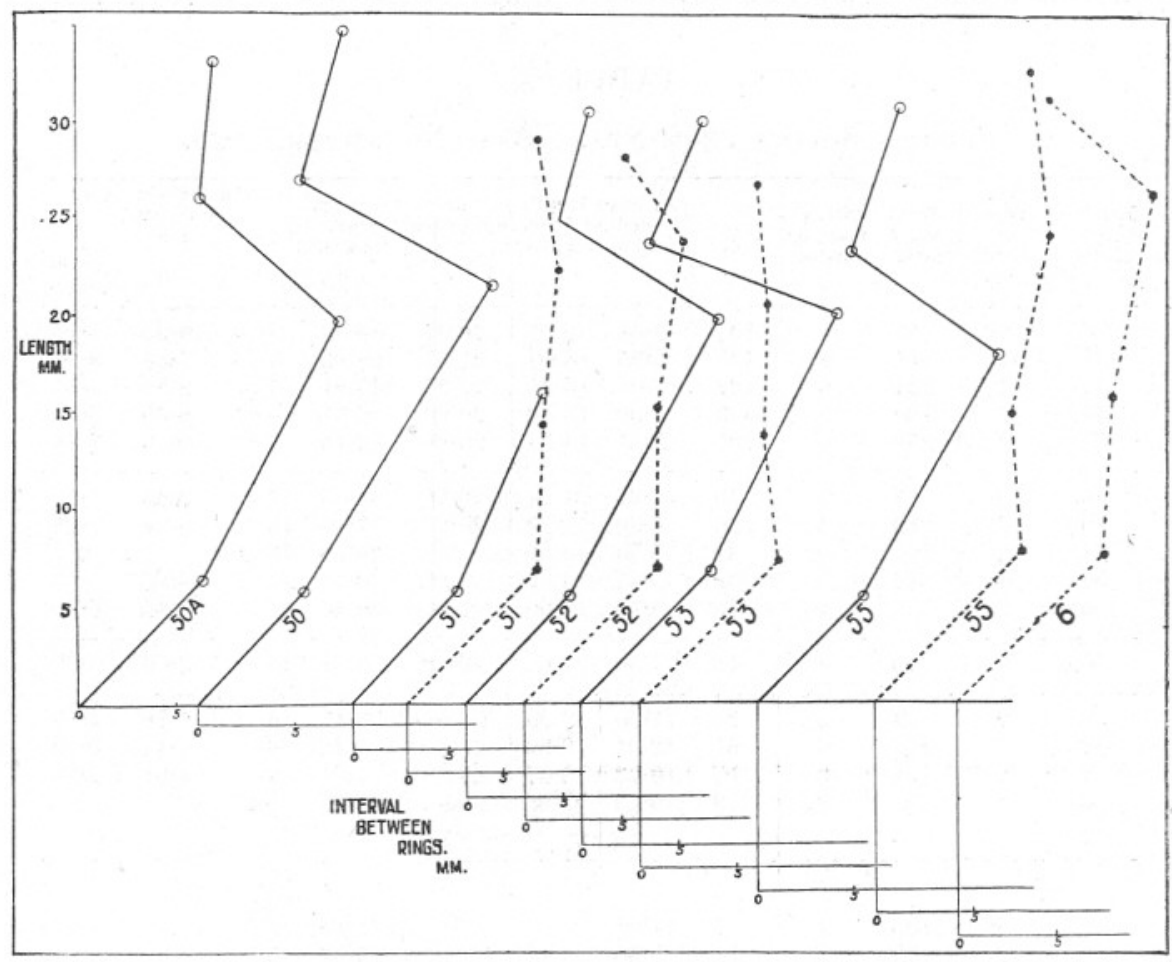

Frc. 9.-Spisula solida. Start Bay, November, 1923.

Continuous Line.' Five-ringed shells.

Broken Line. $\quad$ Six-ringed shells.

The large numbers alongside each graph indicate the Station from which shells were taken.

station of the several types. Only those shells which were true to type are included, all doubtful ones having been discarded. The total number at each station is given, so that it is possible, from the table, to note the number of quite typical shells, but it is probable that a considerable number of each type have been left out as a result of the stringent selection. Fig. 8 (Pl. I) is from a photograph of good specimens of each type, from which the distinctive characters may be learned. In Fig. 9 graphs are reproduced for five-ringed and six-ringed shells from the same stations 
- the average lengths appear as ordinates, and the interval growth* between successive rings as abscissae - and the distinct difference between the two types is well illustrated thereby. It will be seen that the most noticeable difference is in the interval growth between the first and second rings. In the five-ringed shells, this is large in comparison with the initial growth to the first ring (ef. Pl. I, Fig. $8 \mathrm{E}$ and F). Confining attention, for the time being to Station 52, we may enquire whether five of the six growth-disturbances which resulted in the rings on the

TABLE XI.

Spisula Solida from Start Bay, November, 1923, at Station 52. SiX-RINGed Shells.

\begin{tabular}{cccccccccccc}
\hline $\begin{array}{c}\text { Length in } \\
\text { mm. at } \\
\text { 2nd ring. }\end{array}$ & 9 & 10 & 11 & 12 & 13 & 14 & 15 & 16 & 17 & 18 & Total. \\
\hline 16 & - & 1 & - & - & - & - & - & - & - & - & 1 \\
17 & 1 & 1 & - & - & - & - & - & - & - & - & 2 \\
18 & - & - & - & 4 & - & - & - & - & - & - & 4 \\
19 & - & - & 4 & 3 & 1 & - & - & - & - & - & 8 \\
20 & - & - & 2 & 4 & 8 & 2 & 1 & - & - & - & 17 \\
21 & - & - & 2 & 4 & 11 & 8 & 2 & - & - & - & 27 \\
22 & - & - & - & 3 & 5 & 11 & 3 & - & - & - & 22 \\
23 & - & - & - & - & 2 & 5 & 5 & 1 & - & - & 13 \\
24 & - & - & - & 1 & 2 & 3 & 3 & 5 & 3 & 1 & 18 \\
25 & - & - & - & - & 2 & - & 1 & 3 & - & - & 6 \\
26 & - & - & - & 1 & - & - & 1 & - & - & - & 2 \\
27 & - & - & - & - & - & 1 & 3 & - & - & 1 & 5 \\
\hline Total & 1 & 2 & 8 & 20 & 31 & 30 & 19 & 9 & 3 & 2 & 125 \\
\hline
\end{tabular}

six-ringed shells could produce the five-ringed type of shell on the same ground. Obviously, for this to occur, the first disturbance must have taken place before the five-ringed shells appeared at all, so that we must pass over the initial growth to the first ring in the six-ringed shells, and compare the subsequent growth with the whole growth of the fiveringed shells. Thus, the first ring on the five-ringed shells would be produced by the disturbance which caused the second ring on the six-ringed shells.

Table XI is a correlation table for the lengths of the six-ringed shells

* The interval growth is the differences between the lengths of successive rings. 
at the second and third rings respectively. The coefficient of correlation is 69 and the equation representing the one in terms of the other is

$$
\mathrm{L}_{3}=\cdot 427 \mathrm{~L}_{2}+16 \cdot 36 \text {. }
$$

From Table $\mathrm{X}$ we learn that the length of the five-ringed shell when the first ring was formed (that is when the second ring of the six-ringed shell was formed) was $5.47 \mathrm{~mm}$., so that from the above equation, the length at the formation of the second ring should be

$$
(5 \cdot 57 \times \cdot 427)+16 \cdot 36=18 \cdot 70 \mathrm{~mm} .
$$

Actually it was $18.63 \mathrm{~mm}$., which is not greatly different from the value calculated. This result shows that the hypothesis that the five-ringed shell was produced by the last five of the six disturbances which brought about the six-ringed shell, is not an impossible one. The small size of the five-ringed shell at its first ring suggests that it had not been on the ground for the whole period between the first and second growth disturbances. If the disturbances were annual, then the five-ringed shells were spatted towards the end of the growth period of 1918, whereas the six-ringed shells, showing a comparatively large initial growth were spatted at any earlier part of the growth period of 1917.

On Station 53, both six- and seven-ringed shells occur, the former being the more numerous, and by a similar calculation to the above it was found that the six-ringed type could be produced by the last six of the seven disturbances causing the seven-ringed type.

There seems, therefore, to be sound reason for arguing that in general the bulk of the shells on the same station have been subjected to some part of the same series of growth disturbances, the number of rings on a shell indicating the number of disturbances the shell has experienced. Those with fewer rings are younger than those with more, and when it becomes possible to state the times at which the disturbances occur, the rings are a definite clue to age, while the interval between them represents the growth between the successive disturbances.

If the rings are formed annually - a pure assumption at present-then the bulk of the stock was spatted in the year 1917, the average size of these six-ringed individuals varying with the position on the ground. On Station 54, however, the stock is almost purely 1920 spatting. The brood of the year 1921 seems to be almost absent from the area, and that of 1922 is not great.

The fact that individuals of more than one type of shell may occur on the same station suggests a further possible complication. It has already been stated that the bottom soil consists largely of water-wom gravel and stones. This indicates considerable water-movement at the bottom, and it is quite believable that the living shell-fish are themselves 
on occasions rolled along the sea-bottom to another position on the bed. They certainly often present a worn appearance of the shell, consistent with such a view. If such may occur, an individual rolled away from the spot in which it first settled, may come to lie among a stock of others of different size and age. In the course of time, considerable mixing could easily be brought about, bringing together individuals of different age and origin, and producing the effect experienced in the series of hauls now under consideration. The presence of these rolled individuals will make it difficult to determine which of the specimens in a haul were spatted in that position, but it seems fair to conclude that those of the predominant type, at least, have lived there throughout their life.

Other important food-species occurred in the material, but the information derived on rate of growth was not so full as for those already dealt with. It will be most convenient to give a short account for each species.

\section{Mactra stultorum.}

A definite-growth ring may be formed in the first winter after spatting. Individuals spatted in late spring of 1922 formed a ring at a length from $25 \mathrm{~mm}$. to $32 \mathrm{~mm}$. during the winter of 1922-23, and by January 31st, 1924, had grown to from $33 \mathrm{~mm}$. to $39 \mathrm{~mm}$.

\section{LUTRARIA ELLIPTICA.}

On June 7th, 1922, the average size of specimens from Whitsand Bay was $3 \mathrm{~mm}$., while on July 20 th this had increased to $12 \mathrm{~mm}$. On January 25 th, 1924, specimens were taken with a distinct ring at $30 \mathrm{~mm}$. to $33 \mathrm{~mm}$., and of a total length of from $44 \mathrm{~mm}$. to $45 \mathrm{~mm}$. This suggests a growth of $30 \mathrm{~mm}$. to $33 \mathrm{~mm}$. for 1922, and a further growth of $12 \mathrm{~mm}$. to $14 \mathrm{~mm}$. during 1923.

\section{LUTRARIA OBLONGA.}

On July 5th, 1922, fifty-six specimens from Queen's Ground were of an average size of $5 \cdot 1 \mathrm{~mm}$. On August 24th, 1922, one specimen was obtained measuring $22 \mathrm{~mm}$. This would indicate a growth-rate somewhat similar to that of $L$. elliptica.

\section{Nucula Nitida.}

Information on this species is rather of a negative character. Many specimens were obtained, but neither by the comparison of modal lengths for successive samples, nor by the study of the rings on the shells was it possible to gain knowledge on the rate of growth. Tiny specimens 
occurred in almost every month of the year, and the lengths of individuals of a sample did not conform to a distinct mode. The rings were confusing, not lending themselves to simple interpretation for age.

\section{Cultellus pellucidus.}

This important food-species was also well represented. One fact of interest was that on the same day, the average size of individuals from the open channel was much smaller than that of individuals from Bigbury Bay. This observation is mentioned in illustration of the point that care must be taken when comparing average sizes of shells on different occasions - differences in average size can only be significant in relation of growth, when there is evidence that the stock sampled is really of the same age, and has been under similar conditions during the interval between samplings. In Bigbury Bay, individuals spatted in June, 1922, grew to $15 \mathrm{~mm}$. to $20 \mathrm{~mm}$. by the autumn of the same year. Jensen $(1919$, p. 16) states that in the Thisted Bredning, individuals one year old in May, 1912, measured $15 \mathrm{~mm}$. to $20 \mathrm{~mm}$., and those two years old in May, 1913, were about $25 \mathrm{~mm}$. He also refers to growth-rings on the shells, but I am unable to say that the Plymouth specimens showed rings which I could confidently regard as reliable aids to determination of age.

\section{LTTERATURE}

1907. Todd, R. A. Second Report on the Food of Fishes (North Sea, 1904-5) Mar. Biol. Assoc., International Fishery Investigations. Second Report (Southern area), 1904-5, Part I, p. 49. Cd. 3837 .

1917. Blegvad, H. On the Food of Fishes in the Danish Waters within the Skaw. Report XXIV of the Danish Biological Station.

1919. Jensen, P. Boysen. Valuation of the Limfjord I. Report XXVI of the Danish Biological Station.

1920. Lebour, M. V. The Food of Young Fish, No. III (1919). Journ. Mar. Biol. Assoc., Vol. XII, p. 261.

1923. Weymouth, F. W. The Life-history and Growth of the Pismo Clam (Tivela stultorum Mawe), State of California, Fish and Game Commission. Fish Bulletin, No. 7.

1923. Ford, E. Animal Communities of the Level Sea-bottom in the Waters adjacent to Plymouth. Journ. Mar. Biol. Assoc. Vol. XIII, p. 164. 
GROWTH OF LAMELLIBRANCHS.

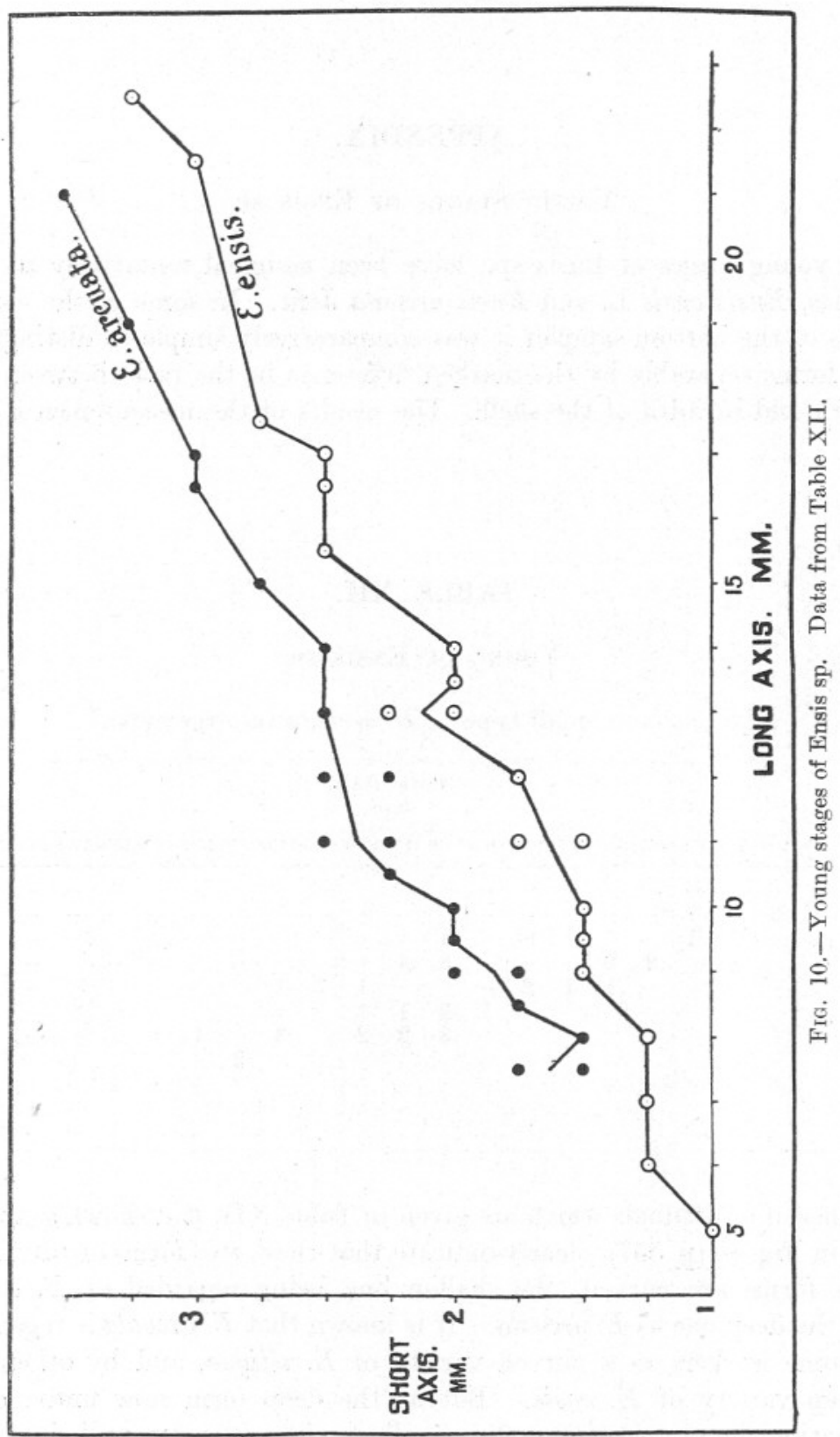




\section{APPENDIX.}

\section{Young Stages of Ensis sp.}

THE young stages of Ensis sp., have been assigned tentatively to two species, Ensis ensis L. and Ensis arcuata Jeffr. In some of the earlier hauls of the bottom-sampler it was comparatively simple to distinguish two forms separable by the marked difference in the ratio between the length and breadth of the shell. The results of the measurements of a

TABLE XII.

Young OF ENSIS sp.

[E. ensis in small type ; E. arcuata in large type.]

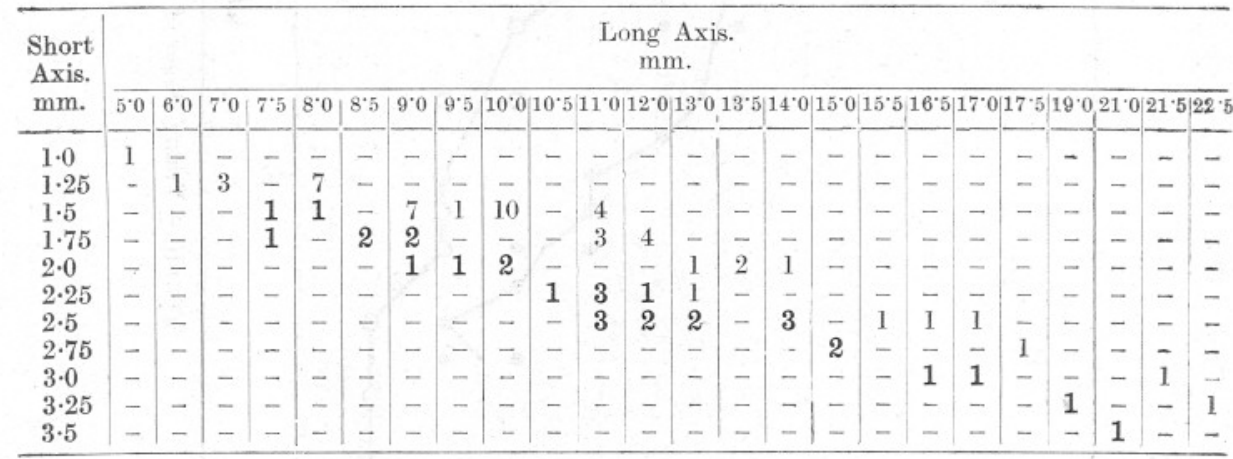

number of individuals which are given in Table XII, and shown graphically in Fig. 10 (p. 557), clearly indicate that these two forms are distinct. Both forms are curved, the shallow one being regarded as $E$. ensis, and the deep one as $E$. arcuata. It is known that $E$. arcuata is regarded by some workers as a curved variety of $E$. siliqua, and by others as a deep variety of $E$. ensis. But as the deep form now under consideration is curved from the smallest size, it may well be that $E$. arcuata should be accepted as a species distinct from both $E$. ensis and E. sitiqua. 
Journ. Mar. Biol. Assoc. XIII.-3.

PLATE I.

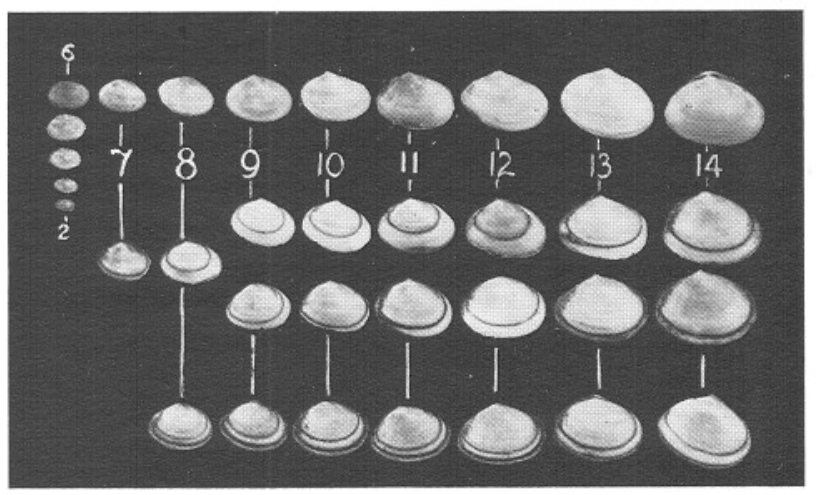

FIG. 3.

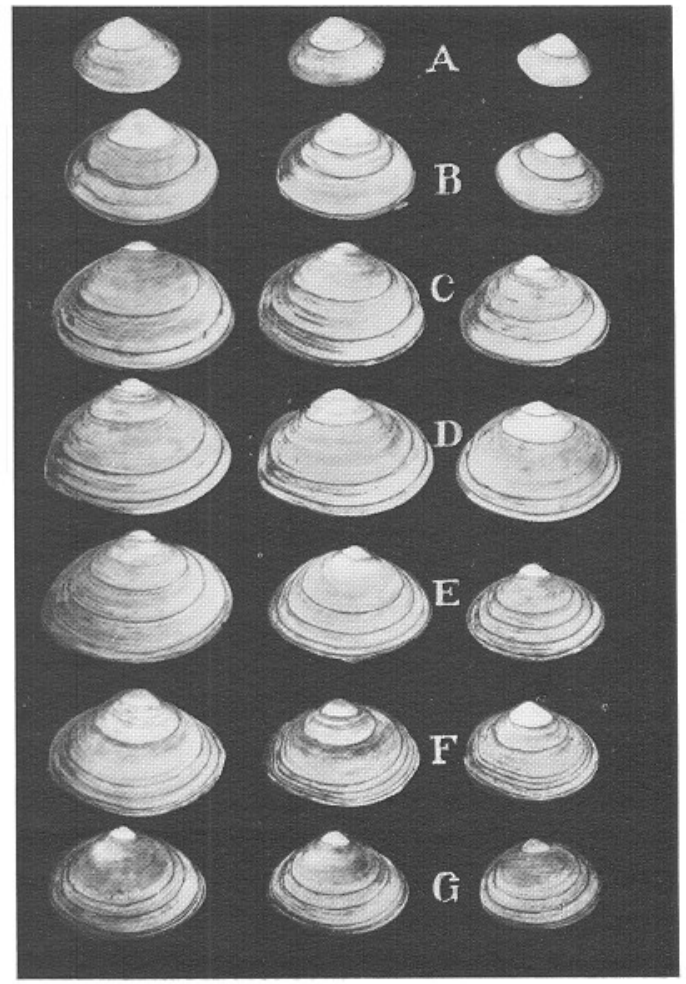

Photo E. F.

Fig. 8.

To face page 558 . 
Journ, Mar. Biol, Assoc. XIII.-3.

PLATE II.

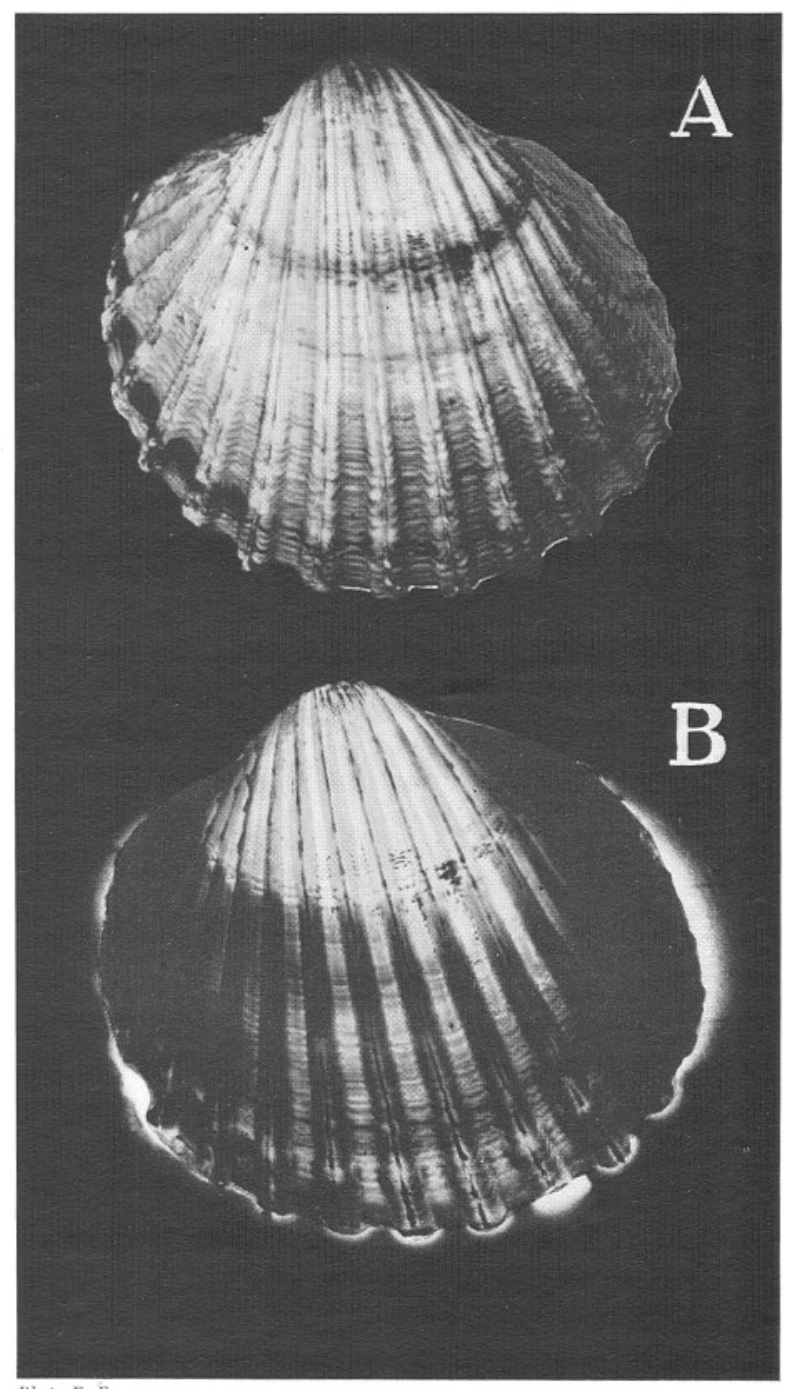

Photo E. F

FIG. 6.

To fuce page 558, after Plate I. 
PLATE III.

Journ. Mar. Biol, Assoc. XIII.-3.

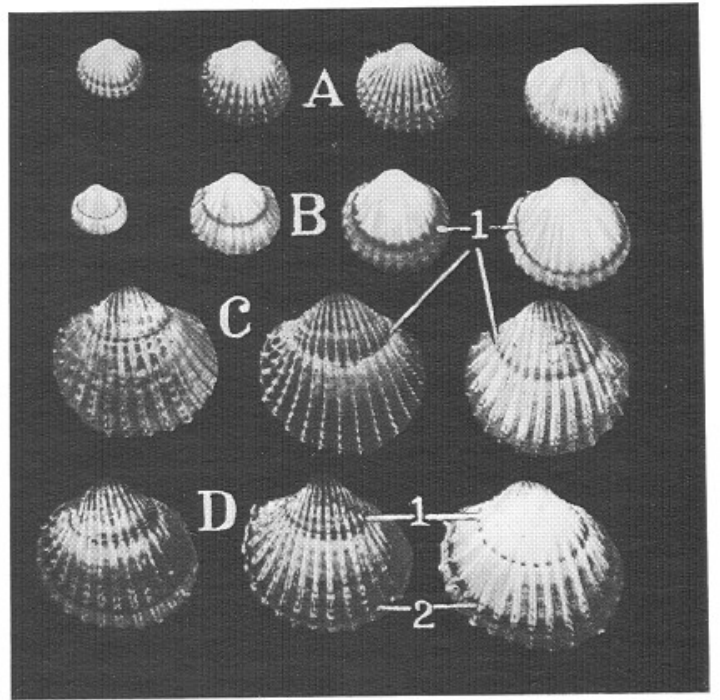

FIG. 5.
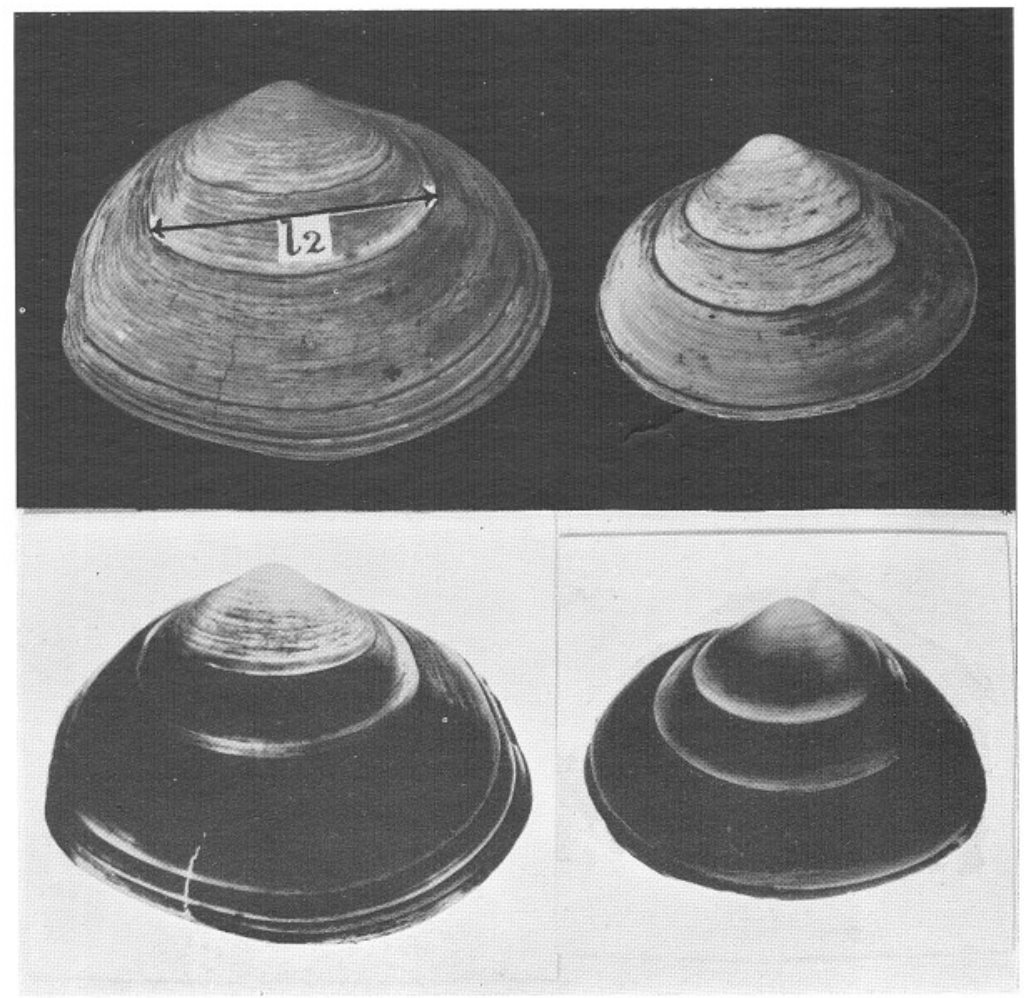

Photo E, $F$.

Fig. 7.

To face page 558, after Plate II. 


\section{EXPLANATION OF PLATES.}

\section{PLATE I.}

FIG. 3.-Syndosmya alba. Bigbury Bay, 1922, 1923, and 1924. Photograph of shells from $2 \mathrm{~mm}$. to $14 \mathrm{~mm}$. in length. Top row without winter ring, middle rows with one winter ring and bottom row with two winter rings.

FIG. 8.-Spisula solida. Start Bay, November, 1923. Reduced from photograph of single valves, to show growth rings.
A. One ring.
B. Three rings.
C. \& D. Four rings.
E. Five rings. Note wide growth between first and second rings.
F. Six rings. Note four rings close together at margin.
G. Seven rings.

\section{PLATE II.}

Frg. 6.-Cardium echinatum. Bigbury Bay, 1924. Enlarged from photographs of same shell.
A. By reflected light.
B. By transmitted light.

\section{PLATE III.}

FIG. 5.-Cardium echinatum. Bigbury Bay, 1922, 1923, and 1924. Reduced from photograph of one valve of each shell.
A. Specimens without winter ring.
Autumn, 1922.
B. Specimens with one winter ring.
May, 1923.
C. , , , , , , January, 1924.
D. ", , two winter rings. May, 1924.

Fis. 7.-Spisula solida. Start Bay, November, 1923. Enlarged from photograph of two shells.

Upper. By reflected light.

Lower. By transmitted light.

$l_{2}$. Length of second ring. 